\title{
UNA TRAYECTORIA ROTA. JUAN DE MATA CARRIAZO, CATEDRÁTICO DE PREHISTORIA E HISTORIA DE ESPAÑA ANTIGUA Y MEDIA DE LA UNIVERSIDAD DE SEVILLA
}

\section{A BROKEN TRAJECTORY. JUAN MATA CARRIAZO, PROFESSOR OF PREHISTORY AND ANCIENT AND MIDDLE AGES AT THE UNIVERSITY OF SEVILLA}

\author{
ALFREDO MEDEROS MARTÍN*
}

Resume: Juan de Mata Carriazo, discípulo de Gómez-Moreno en el Centro de Estudios Históricos, ganó en 1927 la Cátedra de Historia Antigua y Media de España de la Universidad de Sevilla con 28 años, pero no consiguió la Cátedra de Arqueología de la Universidad Central de Madrid en 1931. Desde 1932 fue Director del Instituto-Escuela de Sevilla y desde 1933 de las excavaciones de Itálica (Santiponce, Sevilla). Destinado durante la Guerra Civil a la Universidad de Valencia, entre 1936-38, fue encarcelado 9 meses y medio al final de la guerra y sufrió un Consejo de Guerra en 1940 del que fue absuelto. Vetado por Martínez Santa-Olalla como Comisario Provincial de Excavaciones Arqueológicas de Sevilla y perdida la dirección de las excavaciones de Itálica, orientó su investigación desde 1939 hacia el estudio de la Crónicas castellanas del siglo XV, durante los reinados de Juan II, Enrique IV y los Reyes Católicos y a la historia de la guerra de la conquista de Granada. Nombrado en 1956 como Delegado de Zona del Servicio Nacional de Excavaciones del Distrito Universitario de Sevilla, no pudo reanudar su investigación en Itálica, pero excavó en El Carambolo (Camas, Sevilla) entre 1958-61, sobre el cual redactó en 1965 su principal obra, Tartessos y El Carambolo (1973), donde defendió una génesis autóctona de Tartessos, cuyos orígenes remonta al Calcolítico.

Palabras clave: Juan de Mata Carriazo, Biografía, Catedrático, Prehistoria, Universidad de Sevilla, Italica, El Carambolo.

\begin{abstract}
Juan de Mata Carriazo, disciple of Gomez-Moreno at the Center for Historical Studies, got in 1927 the Chair of Ancient and Medieval Spanish History at the University of Sevilla with 28 years old, but did not get the Chair of Archaeology in the Central University at Madrid in 1931. From 1932 he was Director of the Institute-School of Seville, and since 1933 director of the excavations of Italica (Santiponce, Seville). Destined during the Spanish Civil War to the University of Valencia, among 1936-38, was jailed 9 months and a half at the end of the war and suffered a court-martial in 1940 of which he was acquitted. Banned by Martinez SantaOlalla as Provincial Commissioner of Archaeological Excavations in Seville and lost the direction of the excavations of Italica, focused his research from 1939 to the study of Castilian Chronicles of the fifteenth century during the reign of Juan II, Henry IV and the Catholic Monarchs and the history of the war of conquest of Granada. Appointed in 1956 as Area Delegate of the National Service of Excavations in the University District of Seville, was unable to resume his research in Italica, but dug in the Carambolo (Camas, Seville) between 1958-61, on which he issued in 1965 his main work, Tartessos and the Carambolo (1973), where he defended a native genesis of Tartessos, whose origins date back to the Chalcolithic.
\end{abstract}

Key words: Juan de Mata Carriazo, Biography, Professor, Prehistory, University of Seville, Italica, El Carambolo.

* Departamento de Prehistoria y Arqueología de la Universidad Autónoma de Madrid. Facultad de Filosofía y Letras. Campus de Cantoblanco.28.049 Madrid. E-mail: alfredo.mederos@uam.es 


\section{FORMACIÓN}

Juan de Mata Carriazo Arroquia nació en Jódar (Jaén) el 13 de mayo de 1899. Heredó el nombre de su abuelo paterno, Juan de Mata Carriazo, que había sido médico en Quesada (Jaén) y Málaga. Su padre, Diego Carriazo Delgado, era abogado y Juez Municipal de Quesada, donde habían nacido su abuelo paterno y su abuela Trinidad Delgado. Por parte de su madre, María de los Ángeles Arroquia Mesa, procedía de una familia de caballeros hijodalgos navarros de Pamplona que se trasladaron a inicios del siglo XIX a Jódar, y su abuelo Juan Francisco Arroquia se dedicó al cultivo del olivo (Polaino 1972: xiii, xx, xxii) con su abuela Emilia Mesa, razón por la que su madre fue ha tenerlo en Jódar, aunque residió en Quesada.

Estudió cuatro años matriculado libre de Segunda Enseñanza en el Instituto de Jaén entre 1911-15, recibiendo una educación no convencional, siguiendo las clases en Quesada de su tutor, el sacerdote y capitán carlista Ramón de Rus y Rus, que le hizo leer todos los autores clásicos y le hablaba con entusiasmo de Itálica. La excepción fue el último curso 1915-16, en que residió en Jaén, donde estudiaba en la Biblioteca Provincial, de la cual le dieron una llave por que no iba nadie y estaba habitualmente cerrada, en la cual descubrió la literatura medieval (Carriazo Arroquia 1967: 31-32).

Antes de comenzar sus estudios universitarios, su madre, María de los Ángeles Arroquia, le animó a estudiar en el Seminario de Jaén junto a su primo Juan Francisco Arroquia, pero ambos lo abandonaron durante el primer curso (Carriazo Rubio 2001: 15).

En sus estudios universitarios realizó los primeros dos años comunes en la Facultad de Filosofía y Letras de la Universidad de Granada, 1916-18, el primero matriculado libre, puesto que también estaba matriculado en el Seminario de Jaén, y el segundo como alumno oficial, aunque al contraer "el endémico tifus granadino" tuvo que regresar a Quesada tres meses, entre noviembre de 1917 y febrero de 1918. Como Carriazo señala, "El salto de Jaén a Granada fue para mí casi tan grande como el de Quesada a Jaén (...) En los pocos meses que estuve allí, además del tifus, tuve una novia, conocí un terremoto, me empapé de los monumentos, repartí mis horas de estudio entre la hermosa biblioteca universitaria y los bosques de la Alhambra (...) y gané buenos amigos" (Carriazo Arroquia 1967: 31-32; Polaino 1972: xxvi-xxvii).

Al no haber la especialidad de Historia en la Facultad de Filosofía y Letras de Granada, trasladó su expediente a Madrid donde cursó los dos últimos cursos entre 1918-20. La situación sanitaria no era mejor en la capital y durante los tres primeros meses de su tercer curso la Universidad Central de Madrid estuvo cerrada por una epidemia de gripe, pasando a vivir en una pensión de la calle del Prado, próxima al Ateneo de Madrid. Durante la carrera recibió clases de José Ramón Mélida en Arqueología y de Antonio Vives en Numismática y Epigrafía (Polaino 1972: xxvii- xxviii).

Una vez licenciado fue alumno de Gómez-Moreno, en el curso 1920-21, de la asignatura de doctorado de Arqueología Arábiga, donde fue clave en su decisión de especializarse en arqueología el viaje que realizó con sus compañeros y profesores a Portugal entre el 27 de marzo y el 8 de abril de 1921, durante el cual "Las cualidades y la intimidad de los maestros de la Sección me habían sido reveladas" (Carriazo Arroquia 1977: 51), "en un momento muy aflictivo de mi vida, pues acababa de morir mi madre" (Polaino 1972: xxix). En el viaje, que pasó por Plasencia, Cáceres, Lisboa, Sintra, Leiría, Coimbra, Alcobaça, Batalha y Viseu, participaron Antonio Ballesteros Beretta, su mujer, Mercedes Gaibrois, Andrés Ovejero, Francisco Javier Sánchez Cantón, Elías Tormo, Manuel Gómez-Moreno y 24 estudiantes, incluyendo a Diego Angulo y Carriazo, junto con Virgilio Correia y algunos de sus alumnas, en cuya despedida "hizo llorar a uno de ellos a moco y baba y algo también a alguno de los nuestros" (Gómez-Moreno Rodríguez 1995: 311-315), concretamente Carriazo. En Portugal había quedado deslumbrado de "las bellezas de Portugal. Incluso las que aquellas tres alumnas de la Facultad de Letras de Lisboa (una mestiza y otra anglo-portuguesa) que me dedicaron una edición miniatura de Os lusíadas, y con las que durante mucho tiempo sostuve correspondencia: Magdalena Prieto, Aurora Lebroto Baptista, María Dolce Nunes Ferreira" (Carriazo Arroquia 1972: xlviii).

Antonio Domínguez Ortiz (1997: 11) lo describe perfectamente, "alto, rubicundo, atildado en su porte, exquisito en sus maneras, vestido con sobria elegancia, parecida a la que proporcionan a sus clientes los buenos sastres del West End londinense (...) siempre se sintió un andaluz de pies a cabeza, y nuestra tierra inspiró toda su actividad científica y docente".

En el año académico 1920-21 realizó los cursos de doctorado, donde tuvo como profesores a GómezMoreno y Tormo, realizando su tesis doctoral sobre Las ideas sociales en Juan Luis Vives (Carriazo Arroquia 1923), tema de un trabajo que había realizado en la asignatura de Sociología para Severino Aznar, cuyo tribunal presidió el entonces Decano de la Facultad, Adolfo Bonilla San Martín, autor del libro, Luis Vives 
y la filosofía española del Renacimiento. Tras su lectura, el 3 de octubre de 1923, consiguió el premio extraordinario el 20 de octubre de 1923, un año después que Mergelina, compitiendo con las tesis de Luis Pericot García (1923), La civilización megalítica catalana y la cultura pirenaica, que venía de la Universidad de Barcelona, y había realizado el curso de doctorado en 1918-19, y la de Blas Taracena Aguirre (1923), La cerámica ibérica de Numancia. Eso le permitió impartir docencia como Profesor Auxiliar interino gratuito (Carriazo Rubio 2001: 17) durante el curso 1923-24.

Después del verano, en 1922 se incorporó al Centro de Estudios Históricos en la sección de Arte y Arqueología. En Arte se encontraban Elías Tormo, vicepresidente del Senado, Francisco Javier Sánchez Cantón, Diego Angulo Íñiguez y Enrique Lafuente Ferrari, mientras en Arqueología estaban Manuel Gómez-Moreno, Cayetano de Mergelina, Juan Cabré y Aguiló y Emilio Camps Cazorla.

Aunque estaba en la sección de Arqueología, como recuerda Carriazo (1977: 33) "el trabajo sobre los mss. de [Andrés] Bernáldez fue lo primero que me encargó don Manuel cuando ingresé en el Centro de Estudios Históricos", trabajo que retomó en 1951, por encargo de la Real Academia de la Historia a Gómez-Moreno y Carriazo (1962), que tardaron diez años en finalizar.

Mientras comenzó a prepararse las oposiciones, impartía clases de Historia, Arte y Geografía en el Instituto-Escuela de Madrid, entre las 9 a.m. y 2 p.m., con visitas a los museos, Jardín Botánico o Zoológico de Madrid a partir de las 11 a.m., durante cinco años a los mismos dos grupos de chicos y chicas. Se trataba de un modelo para una futura reforma de la enseñanza secundaria, que propugnaba un número limitado de alumnos por clase, eliminación del libro de texto y de los exámenes, el contacto con la naturaleza y el arte, visitas regulares a museos, exposiciones y monumentos, el estímulo de los deportes, etc., entre los cuales tenían sus hijos Ortega y Gasset y Eugenio d'Ors (Polaino 1972: xxix-xxx), dos hijos de Gómez-Moreno o era estudiante Julio Caro Baroja, lo que le permitió a Carriazo tener un trato personal con sus padres. Almorzaba y cenaba en La Marina de la Calle del Barrio, de 2 a 2.30 p.m. y de 9 a 9.30 p.m., donde pagaba una cantidad fija al mes, después iba a la tertulia en el café El Gato $\mathrm{Ne}$ gro entre 2.30 y 3 p.m., luego estudiaba en la Biblioteca del Ateneo de Madrid, de 3 a 5 p.m., y por las tardes, entre las 6 y 8.30 p.m., trabajaba en la sede de la calle Almagro del Centro de Estudios Históricos. Después de cenar, volvía a la Biblioteca del Ateneo de 9.30 p.m. a 1 a.m. Al salir, si tenía que continuar trabajando, marchaba a un café de la Puerta del Sol, como Levante o Puerto Rico, o a otro tertulia cerca de la Granja El Henar. Finalmente, dormía en la pensión Amiano de la calle de Palma Baja, con desayuno, donde también le lavaban la ropa. Los domingos tenía excursiones fuera de Madrid, con los alumnos del Instituto-Escuela o del Curso de Extranjeros, a las ciudades monumentales de El Escorial, Alcalá de Henares, Aranjuez, Ávila, Segovia, Toledo, etc. (Carriazo Arroquia 1972: xliv-xlv). Su propia educación no convencional durante el Bachillerato, con un tutor en Quesada, le hacía partidario de buscar otras alternativas a los sistemas educativos entonces vigentes.

En ese periodo, "Don Manuel [Gómez-Moreno] me abrió su corazón como un segundo padre. Además de las conversaciones en el Centro [de Estudios Históri$\cos$ ] y en su casa, que pronto fue como la mía, algunas noches, porque él o yo estábamos en trance de confidencias, le acompañaba, a la salida del Centro, hasta el Paseo de la Castellana 80 (ahora 76). En aquel camino oí de sus labios algunas de las cosas que más me han impresionado mi conciencia y mi conducta" (Carriazo Arroquia 1972: xlviii- xlvix).

Las primeras excavaciones individuales de Carriazo van a realizarse durante sus periodos vacacionales en el entorno de la residencia de sus padres y población natal de Quesada en Jaén. Así, ya doctorado, después de excavar unas ruinas romanas de una villa con mosaicos en Bruñel en agosto de 1924, realizó el descubrimiento de enterramientos argáricos en Corral de Quiñones en Quesada durante diciembre de 1924 (Carriazo Arroquia 1925).

\section{OPOSITOR A CÁTEDRAS}

A pesar de la convocatoria de dos cátedras en Santiago y La Laguna, Carriazo optó por retirarse. La Cátedra de Historia de España Antigua y Media, con su acumulada de Moderna y Contemporánea, de la Universidad de Santiago de Compostela, comenzó en noviembre de 1925, con un tribunal formado por Pío Zabala Lera como presidente, Catedrático de Historia Moderna y Contemporánea de España de la Universidad de Madrid; Pedro Bosch Gimpera como secretario, Catedrático de Historia Universal Antigua y Media de la Universidad de Barcelona; José Deleito y Piñuela, Catedrático de Historia Universal de las Edades Antigua y Media de la Universidad de Valencia, Andrés Jiménez Soler, Catedrático de Historia de España de las Edades Antigua y Media de la Universidad de Zaragoza; y 
Claudio Sánchez-Albornoz y Menduiña, Catedrático de Historia Antigua y Media de España de la Universidad Central de Madrid. Pese al fuerte apoyo a Carriazo de Claudio Sánchez-Albornoz, catedrático de esa especialidad en la Universidad de Madrid, la presencia de Pedro Bosch Gimpera, con los apoyos de Jiménez Soler y Deleito, inclinó la balanza a favor de Luis Pericot García (1950-51: 231, 1963: xxiii y 1972-73: 367), quien tomó posesión el 9 de diciembre de 1925.

El propio Bosch Gimpera reconocía en una carta a Ferran Valls i Taberner, del 15 de noviembre de 1925 (Sobreques et alii 1991: 250-251), que al retirarse "Carriazo, que era la fiera del Centro [de Estudios Históricos]", al que valoraba muy por encima que a Mergelina, quedaba abierta la Cátedra de Historia de España Antigua y Media de la Universidad de Santiago de Compostela para Pericot y la Cátedra de Historia de España de la Universidad de La Laguna para Elías Serra Ràfols.

Tras diversas colaboraciones en las Actas y Memorias de la Sociedad Española de Antropología, Etnografía y Prehistoria, que incluían la publicación de la estación argárica del Corral de Quiñones y su tesis doctoral (Carriazo Arroquia 1925a y 1927a), ingresó en febrero de 1927 como Socio en la Sociedad Española de Antropología, Etnografía y Prehistoria.

\section{CATEDRÁTICO DE HISTORIA DE ESPAÑA ANTIGUA Y MEDIEVAL EN LA UNIVERSIDAD DE SEVILLA}

Al dejar Aurelio Viñas Navarro su cátedra en Sevilla, para dirigir el Instituto de Estudios Hispánicos de la Universidad de la Sorbona de París, se convocó la oposición para la Cátedra de Historia de España Antigua y Medieval en Sevilla que Carriazo ganó el 13 de julio de 1927, siendo nombrado el 19 de julio (AGA, 21/20.417). Sin embargo, un mes después falleció su padre, antes de incorporarse en Sevilla, el 29 de septiembre de 1927.

Es importante tener en cuenta que la cátedra se había convocado desde el 2 de febrero de 1925 (AGA, 21/20.417) y es probable que Carriazo se reservase para la cátedra de la Universidad de Sevilla por su origen andaluz, cuya oposición fue la última en realizarse, y explique mejor su renuncia a opositar a las cátedras de Santiago de Compostela y La Laguna.

En Sevilla, tras instalarse en el Hotel San Sebastián, aconsejado por Diego Angulo, contó inicialmente con el poeta Pedro Salinas para conocer bien la ciudad, que vivía también en el hotel, al que conocía por visitar frecuentemente, al igual que Antonio Machado, a Gómez-Moreno en el Centro de Estudios Históricos. Según su primera impresión en octubre, en carta a Gómez-Moreno, "Lo mejor que tiene la Facultad es una biblioteca muy cuca y un cuarto de trabajo muy confortable (...) Hasta ahora tengo cuatro alumnos (...) por las mañanas en la Biblioteca Colombina, cuyos fondos manuscritos empiezo a registrar, y las tardes en la Universidad" (Carriazo Rubio 2001: 20).

Las clases de Carriazo en Sevilla, en su primera época en que fue alumno suyo Antonio Domínguez Ortiz (1989: 275), "contrastaba con la entonces habitual; la ausencia de retórica, la escrupulosa objetividad y la preocupación por el estudio de las fuentes". Su estilo de clase, como recuerda Manuel Bendala (2001: 41), alumno suyo en los cursos 1966-67 y 1968-69, "las impartía siempre de pie, apoyado ligeramente en la mesa o paseando por la tarima, sin notas ni papeles, y hablando muy deprisa y sin pausa con una voz característica, potente y aguda que llegaba a todos por grande que fuera el aula". De acuerdo con otro de sus alumnos del curso 1965-66, Lorenzo Abad (2008: 69), "Sus clases eran un prodigio de dicción, de encadenamiento de ideas, de reflexión, paseaba de un lado a otro del alto estrado, sin sentarse, mientras sus ayudantes, ellos sí sentados a la mesa, lo contemplaban absortos; nunca manejó un solo papel, nunca expuso una sola duda, nunca se le dirigió una sola pregunta, tampoco nunca él lo sugirió (...) el paradigma de la lección magistral”.

En 1929, mientras comenzaba a colaborar con Ramón Carande, Profesor de Derecho, para la publicación del primer volumen del El Tumbo de los Reyes Católicos del Concejo de Sevilla, conoció durante la Exposición Ibero-Americana de Sevilla, a través de la mujer de Carande, María Rosa de la Torre, nacida en Las Palmas de Gran Canaria, a una prima suya también de Las Palmas. Se llamaba María Providencia Ramírez, Maruca, era hija del Director Médico del Hospital Provincial de San Marcos en Las Palmas y la habían invitado a ver la exposición. A los pocos meses se acabaron casando, el 29 de diciembre de 1929, durante las navidades, en el antiguo barrio de Vegueta de Las Palmas, instalándose en Sevilla en la Calle Valparaíso $9,2^{\circ}$, donde nacieron sus dos hijos, Diego el 30 de septiembre de 1930 y Juan el 17 de febrero de 1932 (Carriazo Rubio 2001: 22-23), ambos futuros médicos, y entremedio, una larga estancia en Madrid durante 1931 preparando las oposiciones para la Cátedra de Arqueología en Madrid.

Aparte de la publicación de un artículo sobre ídolos oculados calcolíticos (Carriazo Arroquia 1931a) y otro sobre la presencia de escultura ibérica en Cortijo del 
Álamo (Jódar, Jaén), a 10 km. de Toya (Carriazo Arroquia 1931b), se vio envuelto desde 1933 en la continuación de las excavaciones de Italica (Carriazo Arroquia 1935), que tuvieron una gran repercusión pública en la prensa de la época.

Un tercer frente lo abrió su nombramiento como Director del Instituto-Escuela de Sevilla, o Colegio Oficial de Primera y Segunda Enseñanza de Sevilla, el 2 de febrero de 1932, pues tenía seis años de experiencia docente en el de Madrid, donde también se responsabilizó de la docencia de Historia del Arte y la realización de excursiones. Para simultanearlos, le comunicaba a Gómez-Moreno que "Puse todas las clases de la Universidad y del Instituto en tres días de la semana, para poder dedicar los otros a Itálica" (Algora 1996; Carriazo Rubio 2001: 23-24), a partir de 1933.

En esta etapa acumuló la docencia de algunas otras asignaturas, como la Historia de España en el curso 1928-29 o la Historia de la Cultura en el curso de 193536, que le suponían 2.000 pesetas de incremento de sueldo (AGA, 21/20.417).

\section{LA SUCESIÓN DE MÉLIDA EN LA CÁTEDRA DE ARQUEOLOGÍA DE LA UNIVERSIDAD CENTRAL DE MADRID}

Tras la jubilación de José Ramón Mélida y Alinari el 26 de octubre de 1927 (Castañeda 1934: 10), no se había cubierto la Cátedra de Arqueología de la Universidad de Madrid, aunque Mélida siguió ejerciendo como Director del Museo Arqueológico Nacional hasta el 14 de junio de 1930, con 73 años, cuando fue nombrado director honorario y presidente de la Junta del Patronato (Casado 2006: 365, 383). Pasó a sustituirle Francisco Álvarez-Ossorio y Farfán de los Godos, quien el 2 de junio de 1933 fue también elegido Académico de número de la Real Academia de la Historia. Sólo en el momento de jubilarse Mélida también del Museo Arqueológico Nacional se procedió a convocar la cátedra, cuya docencia estaba siendo cubierta interinamente y gratuita por Antonio García y Bellido, aunque hasta avanzado 1929 no leyó su tesis doctoral.

La plaza se convocó por primera vez en 1930, presidida por José Ramón Mélida, con un tribunal compuesto por José Vicente Amorós i Barra, Pedro Bosch Gimpera, José Ferrandis Torres y Francisco ÁlvarezOssorio, pero fue declarada desierta (García Santos 2003-05: 273 tabla 1).

Esta Cátedra de Arqueología era la plaza que Gómez-Moreno aspiraba para Carriazo, a quien ya le desea en 1927, justo después de sacarse la Cátedra e iniciar "su etapa sevillana, que quiera Dios termine con un salto definitivo aquí a Madrid” (Carriazo Arroquia 1977: 23).

El año de la primera convocatoria de la plaza, Gómez-Moreno comentaba en una carta enviada en diciembre de 1930 a Carriazo (1977: 24), "El Centro [de Estudios Históricos está] muy lánguido, pues con la ida de [Francisco Javier Sánchez] Cantón y [Emilio] Camps que no volverán hasta fin de año, y la de [Manuel de] Terán, que languidece en Calatayud, y perderse la esperanza de que vuelvan Vd. y Mergelina, resulta que todo son bajas. Ahora nos trasladamos al Palacio del Hielo, donde sobra tanto local como faltará dinero y gente para removerlo".

La Cátedra de Arqueología de la Universidad Central, fue vuelta a convocar el 10 de enero de 1931 (AGA, 21/20.505). Aunque Cayetano de Mergelina firmó la plaza y salió suplente de Amorós en el tribunal, no optó a presentarse, aunque era el candidato de más edad, con 41 años y el catedrático más antiguo desde 1925 en Valladolid, ya con 6 años de experiencia, frente a los 4 años de Carriazo, mientras que García y Bellido sólo tenía menos de 9 meses como Profesor Auxiliar.

Sin embargo, debido a la composición del tribunal designado por el Ministerio, en el tránsito de la Dictadura a la Segunda República, se puso en evidencia la debilidad de la posición de Gómez-Moreno, que había sido Director General en el último gobierno de la Dictadura de Primo de Rivero.

El tribunal estaba formado por José Ramón Mélida, como presidente; José Vicente Amorós i Barra como secretario, Catedrático de Arqueología, Epigrafía y Numismática de la Universidad de Barcelona; Hugo Obermaier, Catedrático de Historia Primitiva del Hombre de la Universidad de Madrid; y el Académico de la Historia e historiador de la España musulmana, Antonio Prieto y Vives, los cuales votaron a García y Bellido, que entonces contaba con 28 años, y sólo Gómez-Moreno a Carriazo, entonces con 32 años. Otros dos miembros del tribunal, Andrés Ovejero Bustamante, Catedrático de Historia del Arte de la Universidad Central y Antonio Ballesteros Beretta, Académico y Catedrático de Historia de España no figuran en el acta final (DíazAndreu 2004: xcix-c; Blánquez y Pérez Ruiz 2005: 36 n. 14). También se cita a Ramón Prieto y Bancés, Catedrático de Historia del Derecho de la Universidad de Oviedo desde 1924, en vez de Antonio Prieto Vives (García Santos 2003-05: 273 tabla 1) mientras que Antonio Ballesteros Beretta es considerado suplente (Gracia y Fullola 2006: 359). La propuesta del tribunal presidido por Mélida fue elevada el 4 de diciembre 
de 1931, con 4 votos a favor, y el nombramiento se hizo efectivo el 15 de diciembre, tomando posesión García y Bellido el 17 de diciembre (AGA, 21/20.505).

Mélida intentaba evitar que un alumno de GómezMoreno le sustituyese en la cátedra, y buscó una alternativa ante dos posibles candidatos, ya catedráticos, Carriazo y Mergelina. Para ello contó con el apoyo de Obermaier, que mantenía una alianza de intereses con Bosch Gimpera. Suele además olvidarse frecuentemente que Bosch Gimpera fue uno de los primeros alumnos de doctorado de Mélida, durante el curso 1912-13 (Mederos 1999: 16), y quien le dirigió su tesis doctoral en septiembre de 1913, sobre El problema de la cerámica ibérica (Bosch Gimpera 1915), un año después de que se incorporó a la Cátedra de Arqueología en la Universidad de Madrid en 1912.

Por otra parte, el IV Congreso Internacional de Arqueología, celebrado en Barcelona en Septiembre de 1929, contó en su comité científico, cuyo secretario y coordinador era Bosch Gimpera, con la participación de Obermaier, Taracena, Álvarez-Ossorio y Ferrandis como vocales, Mélida y Gómez-Moreno como Vicepresidentes y la Presidencia por el Duque de Alba.

De las malas relaciones entre Bosch Gimpera y Gómez-Moreno es un buen ejemplo que ya en las oposiciones para la cátedra de Sevilla en 1927, Bosch Gimpera se plantease, si se retrasaba la oposición, que "se podría hacer una mala jugada a Gómez Moreno y a Carriazo" (Gracia, Fullola y Vilanova 2003: 179-180, carta 58), incluyendo a nuevos opositores que compitiesen con Carriazo.

En el caso de Obermaier, la posibilidad de formar en Alemania un especialista en Arqueología e Historia Antigua era una de sus prioridades y ya le sugirió a Martínez Santa-Olalla que se especializase en 1927 en "arqueología clásica, romana y griega. Es muy importante para nosotros en España (...) Usted sabe el rol que juega, por ejemplo, la cerámica griega en los yacimientos ibéricos" (Gracia 2009: 101-102). Pero Martínez Santa-Olalla priorizó la prehistoria y dejó como segunda línea de investigación la época tardorromana, y en particular, visigoda. Fracasada esta opción, García y Bellido, que conocía bien el alemán, era su opción más prometedora. Además, al ganar García y Bellido la oposición, en el curso 1932-33 entró Martínez Santa-Olalla como Profesor Auxiliar Temporal de Arqueología, Numismática, Epigrafía e Historia Primitiva del Hombre, es decir, de las cátedras de Obermaier y de García y Bellido.

No deja que sorprender que no pesasen más los 4 años como Catedrático de Carriazo y su curriculum, frente a los 9 meses como Profesor Auxiliar de García y Bellido. Este último era representante de una nueva generación de estudiantes. Había cursado la carrera de Filosofía y Letras entre 1920-24 y realizado los cursos de doctorado en 1924-25. En el curso 1926-27 comenzó a colaborar en el Centro de Estudios Históricos, preparando una tesis doctoral de Historia del Arte sobre Estudios del Barroco español. Avance para una monografía de los Churrigueras, bajo la supervisión de Elías Tormo, que defendió el 8 de octubre de 1929, con un tribunal formado por Pío Zabala, Manuel GómezMoreno, José Ferrandis, Francisco de Amat y Elías Tormo (Blánquez y Pérez Ruiz 2005: 32-33). Su título de doctor fue expedido el 8 de octubre de 1929 (AGA, $21 / 20.505$ ). Hasta fechas inmediatas a la oposición había sido discípulo de Elías Tormo y Manuel GómezMoreno en la sección de Arte del Centro de Estudios Históricos, bajo cuya dirección había trabajado durante 5 años, entre 1925-30, como él mismo indica (JAE/60131/2, 22-6-1930).

Aunque se licenció en 1924 y se libró del servicio militar como hijo único (JAE/60-131/1), García y Bellido no obtuvo el título de Licenciado hasta el 24 de mayo de 1928, después de haber aprobado una Reválida el 27 de septiembre de 1927 (AGA, 21/20.505).

Durante tres años, 1927-28, 1928-29 y 1929-30, García y Bellido estuvo realizando las sustituciones, quizás como Ayudante encargado de Clases Prácticas, pero sin ningún contrato formal como docente, por lo que la docencia oficial tenía que estar adjudicada a algún profesor que finalmente no la impartía, y se le señala como mérito a la hora de su contratación como Profesor Auxiliar de $2^{\circ}$ grupo de Historia, que fue efectiva por primera vez el 2 de junio de 1930, tomando posesión el 14 de junio, habiendo constancia que ejerció durante 8 meses y 18 días hasta el 2 de marzo de 1931 (AGA, 21/20.505), estando la oposición a la cátedra ya convocada desde el 10 de enero. Debe tenerse en cuenta que al no ser doctor hasta iniciado el curso 1929-30, García y Bellido no estaba autorizado a impartir docencia, ni siquiera como Auxiliar interino gratuito, lo que ya fue posible para el curso 1930-31.

Por otra parte, la comparación del currículum de ambos investigadores revela un notable desequilibrio entre ambos, no favorable para el ganador de la oposición, puesto que Carriazo le duplica en publicaciones, en experiencia docente y en excavaciones, de las que entonces también carecía el nuevo Catedrático de Arqueología, mientras Carriazo comenzó a dirigirlas en 1924, después de doctorarse. Antonio García y Bellido muestra un perfil de Historia del Arte, que comienza a 
dar un giro en 1930, cuando se convoca por primera vez la oposición a la cátedra que queda vacante, hacia Historia del Arte Clásico, para centrarse en 1931, el año de la oposición que sacó.

García y Bellido conocía el alemán pues era profesor particular de español de Franz Wilhelm Mayer-Alberti, hijo de industriales alemanes con residencia en Coblenza-Koblenz, en Renania-Palatinado. Por las fechas que aporta Pérez Ruiz (2008: 66) se observa que durante su primera beca de 3 meses durante el verano, que obtuvo de la Junta de Ampliación de Estudios el 27 de junio de 1930 (JAE/60-131/2-3; Díaz-Andreu 2006: 216-217), para realizar "estudios de Arqueología” durante el periodo vacacional en Alemania, se la concedieron poco menos de un mes después de haber sido contratado como Profesor Auxiliar en la Universidad Central de Madrid (AGA, 21/20.505). Su estancia fue básicamente en Coblenza, la residencia de la familia Mayer-Alberti, donde permaneció entre el 10-20 de julio y del 1 de agosto al 4 de septiembre, salvo 10 días en Berlín, del 21 al 31 de julio, y viajes puntuales a otras ciudades.

Convocada la cátedra de arqueología desde el 10 de enero de 1931, solicitó 4 meses de beca para estudiar "monumentos escultóricos de abolengo clásico importados en España hasta el s. I" el 13 de febrero (JAE/60131/4-5; Díaz-Andreu 2006: 217), que le fue concedida para 3 meses por la Junta de Ampliación de Estudios el 5 de junio (O.M. de 14-7-1931), para el periodo de vacaciones de verano y poder hacer "estudios de Arqueología" durante el verano "en Francia, Italia y Alemania" (JAE/60-131/6). Estuvo en París del 7 al 13 de julio, cuando llegó a Berlín, residiendo en la Hegelhaus al menos hasta el 1 de agosto, realizando también varios viajes (JAE/60-131/9-10). Tenía una carta de presentación de Alfons Adams, director del Centro de Intercambio Intelectual Germano-Español, para el director de la Biblioteca del Antikensammlung de Berlín, donde conoció a Gerhart Rodenwaldt y estuvo también en Coblenza y Bonn (Pérez Ruiz 2008: 67 fig. 1, 70 n. 15, $73)$, pero no hay datos precisos sobre su posterior estancia y visitas en estos tres países. Es interesante tener en cuenta que en la Universidad de Bonn estuvo como lector Martínez Santa-Olalla hasta ese verano de 1931. Regresó antes de finalizar la beca, a los 2 meses y 12 días, al convocarse la oposición de la cátedra (JAE/60131/11), hacia el 21 de septiembre y no el 7 de octubre cuando finalizaba la beca.

Convocada la cátedra de arqueología desde el 10 de enero de 1931, a inicios del verano de 1931, volvió a obtener el 18 de junio otra beca de 3 meses para el periodo de vacaciones de verano de la Junta de Ampliación de Estudios y poder hacer "estudios de Arqueología" durante el verano "en Francia, Italia y Alemania", visitando en Alemania al menos Coblenza, Berlín y Bonn, firmándole Alfons Adams, director del Centro de Intercambio Intelectual Germano-Español, el 19 de junio, una carta de presentación para el director de la Biblioteca del Antikensammlung de Berlín, donde conoció a Gerhart Rodenwaldt (Pérez Ruiz 2008: 67 fig. 1,70 n. 15, 73), pero no hay datos precisos sobre su estancia y visitas en estos tres países. Es interesante tener en cuenta que en la Universidad de Bonn estuvo como lector Martínez Santa-Olalla hasta ese verano de 1931.

Catedrático de Arqueología desde el 15 de diciembre de 1931, solicitó el 27 de febrero de 1932 una beca de viaje por Italia, Sur de Francia, París y Berlín de "6 meses por lo menos" para el "estudio sobre la época de las colonizaciones en España” (JAE/60-131/15; DíazAndreu 2006: 217) que le fue concedida para 6 meses por la Junta de Ampliación de Estudios el 24 de junio (O.M. de 1-7-1932) con 600 pesetas mensuales, frente a las 425 pesetas antes de ser catedrático (JAE/60131/6 y 16). Sabemos que estaba en Berlín el 20 de julio, cuando volvió a residir en la Hegelhaus, (JAE/60131/17), a donde debió llegar el día 6 (JAE/60-131/23), pero en su mínima justificación de agosto, octubre y noviembre en una cuartilla, no pone ningún detalle, tampoco dirección, ni se trata de una carta, aunque indica Berlín, y tampoco presenta ningún papel para justificar el mes de septiembre (JAE/60-131/19-21). Sobre viajes sólo indica que en octubre viajó a Dresden y Leipzig, ambas en Sajonia, al Sur de Berlín (JAE/60131/20). Al menos a inicios de diciembre sabemos que estuvo en el Pergamon Museum según el diario de su mujer, García de Diego (Pérez Ruiz 2008: 67, 69), regresando a Madrid hacia el 5 de diciembre (JAE/60131/23). Ese curso de 1932-33 se había incorporado Gerhart Rodenwaldt a la Cátedra de Arqueología Clásica de la Friedrich-Wilhelms-Universität, y aunque Pérez Ruiz (2008: 73 n. 24) considera que "debió asistir" a su seminario, sólo hay constancia de una visita en 1935 y no existe correspondencia entre ambos en los archivos personales de ambos investigadores, salvo dos cartas en 1931, después de la primera visita a Berlín de García y Bellido de 10 días, cuando se conocieron.

Renunció a un mes de su beca, del 6 de diciembre de 1932 al 6 de enero de 1933 (JAE/60-131/23), porque se le había concedido por la Real Academia de la Historia la beca Conde de Cartagena, con mayor dotación, para una estancia en Italia, Grecia y Turquía, solicitando el 31 de enero a la Junta de Ampliación de 
Estudios ser considerado pensionado y exento de docencia que le fue concedido el 28 de febrero (O.M. de 16-3-1933) (JAE/60-131/22 y 25). Ambas becas implican que García y Bellido estuvo exento de clases desde septiembre de 1932 hasta marzo de 1934, siendo sustituido por Martínez Santa-Olalla, Profesor Auxiliar Temporal de Arqueología, Numismática, Epigrafía e Historia Primitiva del Hombre en la Universidad de Madrid desde el curso 1932-33.

Cuando obtuvo la cátedra carecía estrictamente de libros publicados, hasta varios años después cuando vio la luz Los hallazgos griegos de España (García y Bellido 1936), pues difícilmente contabilizarse como tal una de las cartillas de arquitectura española, La arqueología romana en España (García y Bellido 1929b), de extensión menor a un artículo, y lo más aproximado es la suma de los dos artículos con 117 páginas en total del resumen de su tesis doctoral, Estudios del barroco español. Avances para una monografía de los Churrigueras (García y Bellido 1929a y 1930a). Sus artículos incluyen trabajos sobre la cerrajería artística madrileña (García y Bellido 1925 y 1928a), arte cristiano del Museo del Prado (García y Bellido 1926), Rutilio Gaci (García y Bellido 1928b) y el arquitecto Francisco Bautista (Tormo y García y Bellido 1928). Tras una nota de dos páginas sobre dos esculturas clásicas españolas (García y Bellido 1930b), es en 1931 es cuando publica los dos trabajos de Arte Clásico que aporta en la oposición, las relaciones entre el arte etrusco y el ibérico (García y Bellido 1931a), también resumido en tres páginas (García y Bellido 1931b), y la bicha ibérica de Balazote (García y Bellido 1931c). En total, suma 12 artículos. Su primera recensión en arqueología fue también de 1931, dedicada significativamente a un trabajo de Mélida sobre el disco de Teodosio.

El aspecto más notable de García y Bellido es la solvencia que exhibe en sus dos artículos sobre Arte Clásico y su demostración de que está al día en los temas en discusión y última bibliografía. Su artículo sobre Las relaciones entre el Arte etrusco y el ibero, lo elige para discutir el entonces reciente artículo de Schulten (1930), Die Etrusker in Spanien, que no tenía buenas relaciones con Obermaier, rechazando parte de sus argumentos sobre los que indica que "Los apoyos arqueológicos que busca no llegan a ser lo suficientemente sólidos para sostenerla. Es preciso llegar a la segunda mitad del siglo VI, o a la plenitud del V, para empezar a hallar algo que pueda ser etrusco o influencia suya en nuestra Península", recalcando que "es mucha casualidad que ninguna de aquellas primitivas colonias etruscas en Andalucía y Levante, que Schulten supone, hayan dado aún señales arqueológicas de su existencia" (García y Bellido 1931a: 127), lo que le costó no ser citado por Schulten durante años. En el mismo muestra como se comunica por vía epistolar con investigadores alemanes para discutir aspectos del artículo como Robert Zahn, director del Antiquarium -Antikensammlung del Altes Museum- de Berlín entre 1931-36 o con Paul Jacobsthal, profesor en la Universidad de Marburg (García y Bellido 1931a: 132 n. 6 y 140 n. 2).

Su segundo artículo, La bicha de Balazote (García y Bellido, 1931b: 250), propone un detenido análisis de una escultura estudiada entonces recientemente por Bosch Gimpera (1928) en el artículo, Relaciones entre el Arte ibérico y el griego, quien había sido miembro del tribunal de la oposición de 1930, y de otro de Mélida (1896) con el mismo título, presidente del tribunal en las oposiciones de 1930 y 1931. En el mismo menciona datos que le ha proporcionado Obermaier y apunta la orientación grecocentrista que culminará en su primer libro sobre Los hallazgos griegos de España (García y Bellido 1936). Desde su punto de vista, 'Nuestra 'Bicha' de Balazote, pese a su aspecto anticlásico, es hija de helenos (...) Nos inclinamos a creer provisionalmente que ha de ser del siglo V, entrado, $\mathrm{y}$ aún pudiera ser que del IV. En una palabra, la 'Bicha' de Balazote sería obra greco-ibérica del tiempo de los bronces más viejos y mejores de Despeñaperros y la Luz, de las piedras del Cerro de los Santos, de la serie de esfinges ibéricas y de la Dama de Elche (...) También conviene recordar, como Bosch y Lantier afirman (y nosotros con ellos), que la arqueología fenicia o púnica es pobre en extremo en todo el Mediterráneo occidental" (García y Bellido 1931b: 268-269).

El currículum de Carriazo cuenta con 31 publicaciones, pero 8 son reseñas cortas, 2 reseñas largas y 1 artículo local. Descontándoselas, cuenta con 1 libro y 19 artículos. El libro corresponde a la crónica de Mosén Diego de Valera (Carriazo Arroquia 1927c), su obra más importante y estrictamente el único libro aportado por los dos opositores, con 154 páginas de estudio introductorio y 314 páginas de transcripción de la crónica. Difícilmente tampoco puede considerarse como libro a la cartilla de arquitectura española sobre $A r-$ quitectura prehistórica (Carriazo Arroquia 1929a) que tiene 16 páginas y el breve texto del Alcázar de Sevilla (Carriazo Arroquia 1930) con 28 páginas, aunque sí podría considerarse así al largo resumen de 85 páginas de su tesis doctoral sobre Las ideas sociales en Juan Luis Vives (Carriazo Arroquia 1927a), al igual que sucede con el resumen de la tesis de García y Bellido. Sus artículos recorren todo el arco cronológico, prehistoria 
con ídolos calcolíticos (Carriazo Arroquia 1931a) y su excavación en el yacimiento argárico de Quesada (Carriazo Arroquia 1925a), ibérico con las esculturas del Cortijo del Alamo (Carriazo Arroquia 1931c), cerámica sigillata (Carriazo Arroquia 1925c), legislación romana de la Lex Coloniae Genetivae Juliae (Carriazo Arroquia 1931d), sarcófagos paleocristianos (Carriazo Arroquia 1925d, 1926a y 1931b), el primero de los cuales le valió elogios por Eugenio d'Ors en sus glosas que publicaba en el $A B C$ el 7 de septiembre de 1926, el viaje de Licurgo que recoge Plutarco (Carriazo Arroquia 1924), historia medieval (Carriazo Arroquia 1925e y 1929b) e historia del arte (Carriazo Arroquia 1925d, 1927 b y 1929c).

Ciertamente, Carriazo cuando ganó su cátedra en Sevilla también tenía 28 años, y contaba con 1 libro y 10 artículos en su currículum, en comparación con los 12 artículos de García y Bellido, pero esta oposición era especial por ser para la Universidad Central de Madrid, la más importante y la única donde se podían dirigir tesis doctorales, de ahí que García y Bellido tuviese que competir con un catedrático ya con 4 años de experiencia. En su favor hay que decir que no falló a las expectativas que en él pusieron Obermaier o Mélida, como demuestra su brillante trayectoria investigadora, pero es obvio que lo lógico es que hubiera sacado una Cátedra en Arqueología unos pocos años después. Julio Martínez Santa-Olalla, que iba muy por delante de él, y ya había estado 4 años en el extranjero formándose como deseaba Obermaier, no obtuvo su cátedra hasta 1936.

La desmoralización de Carriazo tras perder la oposición se unió a su casi inmediato nombramiento como Director del Instituto-Escuela de Sevilla el 2 de febrero de 1932 y el simultáneo nacimiento de su segundo hijo el 15 de febrero de 1932, que sólo se separaba del más pequeño 15 meses, provocando que entre 193236, hasta el estallido de la Guerra Civil, su producción científica prácticamente desaparece, salvo un artículo sobre una estela de Quesada (Carriazo Arroquia 1932) y dos sobre las excavaciones en Itálica que inició en 1933 (Carriazo Arroquia 1935a y 1935b), las cuales le absorbieron la mayor parte de su tiempo hasta 1936.

Resultado de la oposición, Gómez-Moreno y Ballesteros se retiraron el saludo. "Un problema académico, en que se vieron involucrados Gómez-Moreno y Ballesteros, motivó el enfado de éste, que negó a aquel el saludo (...) Mi padre que era el receptor, no el agente del enfado". La situación se resolvió al enfermar seriamente en el Crucero de 1933 el hijo de Ballesteros, interesándose Gómez-Moreno por su salud a través de su mujer, lo que motivó las disculpas de Ballesteros (Gómez-Moreno Rodríguez 1995: 455-456).

Un buen resumen de la situación resultante un año después de la oposición la recoge Luis Pericot (1972: 16) durante dicho Crucero, donde participaron las facultades de Filosofía y Letras de las universidades de Sevilla, Madrid, Valladolid, Zaragoza, Valencia y Barcelona, "don Manuel [Gómez-Moreno] no sintió excesivo afecto por la ciencia y erudición extranjeras y lamentó muchas veces, en sus conversaciones conmigo, la relación que nuestra escuela de Barcelona mantenía con sabios prehistoriadores de más allá del Pirineo. Era inevitable que se produjeran roces entre él y una gran figura de la Prehistoria a la cual las circunstancias internacionales convirtieron en ciudadano español, el profesor Hugo Obermaier, que representaba los rigurosos métodos que para su trabajo exigía la Prehistoria moderna. Tales roces habían de terminar en una escisión que nos afectaba, ya que la escuela de Barcelona fundada por Bosch Gimpera, formado a su vez en Alemania, se hallaba científicamente ligada al profesor Obermaier (...) Quienes recuerden todavía el comedor del 'Ciudad de Cádiz' en su fantástico derrotero de mes y medio por el Mediterráneo [15 junio-2 agosto 1933], recordarán que la escisión a que me refiero se simbolizaba en las dos alas del comedor principal”, "[García y] Bellido, con Taracena y conmigo [Pericot], acompañábamos a D. Hugo Obermaier en la mesa del rincón del comedor del 'Ciudad de Cádiz', en la situación opuesta a donde se sentaba D. Manuel Gómez Moreno con su hija M. ${ }^{a}$ Elena y sus discípulos Mergelina y Carriazo" (Pericot 1975: 13-14). En este sentido, Elena GómezMoreno (1995: 419) señala a "Obermaier con su pequeño grupo de prehistoriadores, siempre al margen de la vida colectiva".

No cabe descartar que este acontecimiento influyera significativamente en la decisión de Gómez-Moreno de retirarse de la Universidad a inicios de 1935, un curso después del crucero por el Mediterráneo, pues cumplía 65 años en febrero, aunque podía continuar hasta los 70, "por considerar fracasada su labor en la Ciudad Universitaria” (Gómez-Moreno Martínez 1951-58/1977: 59). Además estaba irritado por el traslado de las clases desde el curso 1933-34 a la nueva Ciudad Universitaria en Moncloa, cuya primera facultad en abrirse fue Filosofía y Letras, pues los alumnos y el propio Gómez-Moreno tenían que trasladarse por la tarde, sin medios de transportes adecuados, y con insuficiente material docente como libros, fotos y diapositivas, lo que provocó la ausencia de los oyentes habituales y un drástico descenso del número de alumnos 
(Gómez-Moreno Rodríguez 1995: 465-466). Paralelamente, se mostraba preocupado por la evolución de los acontecimientos políticos de la Segunda República, pues participó en la restauración del Tesoro de la Cámara Santa de Oviedo, tras la Revolución de los mineros asturianos de 1934.

La publicación por Bosch Gimpera (1932) del libro Etnología de la Península Ibérica fue otro golpe que le había afectado bastante, como le comentaba en una carta personal que le dirigió el 26 de enero de 1933, "Acabo de hojear con algún detenimiento su último y magnífico libro sobre la 'Etnología de la Península ibérica'. Enhorabuena! Y dispénseme que acuse recibo del general menosprecio que sin reserva alguna hace de toda mi pequeña labor arqueológica: el absoluto silencio de mi nombre casi hasta el final del libro y la nota que a la postre me dedica, son, por omisión y por comisión una prueba contundente. Hasta ni siquiera se toma trabajo en desechar lo que yo ipobre tonto ilusoj creía labor científica en mi 'Los iberos y su lengua' [GómezMoreno 1922] (...) Iba a hacer una cosita muy pequeña sobre cerámica primitiva [Gómez-Moreno 1933] y se me quitan las ganas y se me cae la pluma! (...) pero siquiera entrar en turno entre las miles de citas que llenan el pie de las páginas de V es curioso! (...) Queda V amo y señor de la Historia de España (...) sólo sé, en aras de una amistad que por mi parte mantendré siempre, le felicito cordialmente. Tuve ilusión, lo confieso, en otros tiempos de ayudar a hacer una prehistoria española, sin ir mirando lo que nos cuentan de afuera" (Gracia 2003: 57 n. 20). Bosch justifica sus comentarios en que el libro de La Novela de España de Gómez-Moreno (1928a) le llegó cuando estaba corrigiendo las pruebas del apéndice de la Etnología (Bosch Gimpera 1980: 163), aunque este trabajo de Gómez-Moreno se redactó en 1924 y se publicó en 1928. Este proyecto de escribir una síntesis de la Prehistoria de la Península Ibérica lo cumplió casi 25 años después (Gómez-Moreno 1958).

\section{LAS EXCAVACIONES DE ITÁLICA ENTRE 1933-35}

Las campañas de Andrés Parladé, Conde de Aguiar, habían tenido como prioridad la localización y excavación de mosaicos romanos, poniendo al descubierto más de 20, pero como indica Carriazo (1982b: 37), "No hay ni una sola manzana, ni una sola casa, ni un solo tramo de calle, excavado por completo". Pero el Conde de Aguiar dimitió del cargo porque había perdido mucha vista (Carriazo 1935b: 311 y 1982b: 36).
Fue nombrado Delegado-Director de las excavaciones de Itálica el 5 de abril de 1933 por el malagueño Ricardo de Orueta y Duarte, Director General de Bellas Artes entre abril de 1931 y diciembre de 1933. La decisión vino de un historiador del arte que había sido compañero de Carriazo (1982b: 37) en el Centro de Estudios Históricos entre 1922-27. Accedía así al yacimiento del que siempre le hablaba su tutor de bachillerato, Ramón de Rus.

En las campañas dispuso de una subvención de 15.000 pesetas en 1933 y de 20.000 pesetas en 1934 (Carriazo Arroquia 1973: 16), 19.000 en 1933 y 30.000 en 1934 según Díaz-Andreu (2003: 58 tabla 1), iniciando la campaña de 1933 el 10 de octubre (Carriazo Arroquia 1982b: 35). El resultado más evidente fue la excavación de "cuatro manzanas de casas, insulae, con porciones de las colindantes; y los diez tramos de calles, correspondientes a seis vías o alineaciones, que las rodean" (Carriazo Arroquia 1935b: 305). De ellas presentó el estudio de la denominada manzana del Gimnasio, de 46 x 63 m., que había empezado a ser excavada por el Conde de Aguiar en la campaña de 1924-25 (Carriazo Arroquia 1935b: 305-306, 310), tratando de afrontar el primer estudio planimétrico y urbanístico del yacimiento. Sólo muchos años después de la Guerra Civil publicó la excavación de la puerta y un tramo de muralla de $85 \mathrm{~m}$. con dos torres, que se abría hacia el Anfiteatro, de la campaña de 1935, dejando también al descubierto "dos calles Norte-Sur (cardos) y seis tramos de calles Este-Oeste (decumanas)" (Carriazo Arroquia 1982b: 40-43).

En su formación le ayudó su participación previa en una campaña de las excavaciones en Pompeya, que entonces dirigía el Sopraintendente de la Antichitá della Campania, Amadeo Maiuri (Carriazo Arroquia 1982b: 43), que mejoró con una beca de la Junta de Ampliación de Estudios que le permitió visitar la excavación de Ostia que dirigía Guido Calza durante el verano de 1934 (Carriazo Arroquia 1935b: 318). La beca contemplaba visitas durante el verano a Italia, Francia e Inglaterra (AGA 21/20.417).

Las excavaciones de Itálica tuvieron una gran repercusión mediática, al poderse apreciar mejor su estructura urbana y así el periódico católico de derechas, El Debate, indicaba como titular en primera y segunda página el 18 de enero de 1935, que "Por fin, se descubre la ciudad de Itálica, que promete ser una Pompeya española" (El Debate, 18-1-1935: 1-2), lo que despertó celos en Sevilla y en Madrid, y acabó costándole futuros disgustos. 


\section{LA GUERRA CIVIL}

El inicio de la Guerra Civil, el 18 de julio de 1936, sorprendió a Carriazo en Madrid trabajando en la Biblioteca Nacional para los primeros volúmenes de la Colección de Crónicas Españolas, los cuales se los había encargado Ortega y Gasset para Espasa-Calpe en 1935, de los que se publicaron tres volúmenes inmediatamente después del final de la guerra (Carriazo Arroquia 1940a, 1940b y 1940c), a la vez que participaba en "tribunales de cursillistas". Se había desplazado de su domicilio habitual en Sevilla, en la calle de Valparaíso $9,2^{\circ}$, a Madrid con su mujer y los dos hijos al acabar las clases, desde el 28 de junio, residiendo en la pensión Urzaiz de la Gran Vía. Por ello, iba casi diariamente a la sección de manuscritos de la Biblioteca Nacional y si no a la Biblioteca de la Real Academia de la Historia, y continuó asistiendo, ya producida la sublevación, hasta que se cerró en octubre la sección de manuscritos, citando entre sus testigos a Julián Paz y Martín de la Torre, funcionarios de la Biblioteca Nacional. Cerrada ésta, continuó trabajando en la Biblioteca de la Real Academia de la Historia, mientras corregía pruebas en su casa para Espasa-Calpe, que por la inestabilidad política y prolongación de la estancia en Madrid había buscado en la calle Velázquez $69,2^{\circ}$ izquierda (AGA 21/20.417), alquilada a la esposa de Juan Ramón Jiménez, Zenobia Camprubí (Carriazo Rubio 2001: 25), esperando ver como evolucionaba la guerra.

Siguiendo la Orden Ministerial de 10 de octubre de 1936, se presentó en la Facultad de Filosofía y Letras de la Universidad Central de Madrid, donde quedó adscrito, por lo que participó en una Junta de Facultad del 17 de octubre. Eso le permitió seguir cobrando el sueldo para su mantenimiento y el de su familia, desplazados todos en Madrid (AGA 21/20.417). El 15 de octubre también se presentó Cayetano de Mergelina, que tenía a su cargo a Gratiniano Nieto Gallo y a Joaquín Pérez Villanueva, y es probable que la decisión la hayan tomado conjuntamente (AGA 21/20.360).

Con la evacuación por el Gobierno de la República de Madrid, Carriazo fue destinado a incorporarse a la Universidad de Valencia a comienzos de noviembre de 1936, junto con otros catedráticos (Carriazo Arroquia 1977: 26; Carriazo Rubio 2001: 25). Allí empezó viviendo en la vivienda de Jaime Verdu y su familia, situada en la calle de Cirilo Amorós, 67, $2^{\circ}$ (AGA 21/20.417).

Para tratar de continuar las clases, la República decidió emitir una orden de funcionamiento conjunto en Valencia de las Universidades de Madrid, Valencia y
Murcia, ordenando el desplazamiento de los profesores residentes en Madrid, a la que había quedado adscrita Carriazo, sin embargo, las clases no dieron comienzo tampoco en Valencia. Cerrada la universidad y obligado a justificar otra ocupación el personal docente para seguir cobrando su sueldo, en Valencia fue nombrado Secretario de la Subsección de Excavaciones del Consejo Central de Archivos, Bibliotecas y Tesoro Artístico desde el 10 de marzo de 1937 (Gaceta del 14-337), por su prestigio como director de las excavaciones de Itálica entre 1933-35, cargo que inicialmente se había pensado para Blas Taracena, pero se encontraba con los sublevados. Es posible que en su nombramiento tuviese apoyo de Gómez-Moreno desde Madrid. Desde el 10 de marzo de 1937 cobró 10 pesetas diarias como dietas por desplazamiento en Valencia. Allí realizó la excavación de un hallazgo fortuito, una necrópolis romana en el Campo de Sagunto, uno de cuyos sarcófagos considera "acaso, el más antiguo testimonio del cristianismo en el Levante" (AGA 21/20.417).

Con la nueva ayuda económica de 10 pesetas diarias, se trasladó a vivir con su familia a la población de Alfara de Aljimia (Valencia) en mayo de 1937, donde permaneció hasta octubre (AGA 21/20.417), viviendo allí todo el verano de 1937. Entre sus primeras actuaciones fue el inventario de lo que se pudo recuperar del tesoro de la Catedral de Cuenca el 3 de mayo de 1937 (Carriazo Rubio 2001: 26 n. 41). Participó simultáneamente en el Centro de Estudios Históricos del País Valenciano creado en junio de 1937 (Mancebo 1988: 93).

Durante el verano, la Republica decidió reiniciar de nuevo las clases a comienzo del curso 1937-38, por lo que por Orden del Ministerio de Instrucción Pública y Sanidad del 15 de agosto (Gaceta del 31-7-37) fue destinado a la Universidad de Valencia para impartir la asignatura de Historia de España Antigua y Media, presentándose el 11 de septiembre e impartiendo un cursillo sobre "Fuentes de la España Antigua". Por ello regresó a Valencia con su familia a mediados de octubre, viviendo en la Avenida del 14 de Abril (AGA 21/20.417).

El 1 de marzo de 1938, Bosch Gimpera, Pericot y Carriazo firmaron un manifiesto de intelectuales en apoyo de la victoria republicana, publicado en la prensa (Quero 2002: 169), que puede leerse en La Vanguardia de ese día, Los intelectuales de España, por la victoria total del pueblo.

Su labor como Secretario de la Subsección de Excavaciones del Consejo Central de Archivos, Bibliotecas y Tesoro Artístico la debió realizar con cierta normalidad hasta el 5 de marzo de 1938, cuando dejó de 
cobrar sus dietas por desplazamiento. Este organismo, el Consejo Central de Archivos, Bibliotecas y Tesoro Artístico, y sus miembros fueron desplazados a Barcelona, pero Carriazo indica que decidió permanecer "en Valencia, contra todos los requerimientos, cuando tales organismos se desplazaron a Barcelona”. Suprimido el complemento económico y realizando su labor de forma gratuita en el Consejo Central de Archivos, solicitó al Ministerio de Instrucción Pública mantener la dieta de 10 pesetas diarias como profesor desplazado en la Universidad de Valencia el 3 de junio de 1938, que le fue rechazado 6 días después (AGA 21/20.417).

Con problemas para mantener a su familia, ese mes de junio o a inicios de julio se desplazó a Quesada (Jaén), a casa de su hermano Ángel Carriazo Arroquia, farmacéutico en Linares en la farmacia del Hospital Militar (AGA 21/20.417). En su pueblo de Quesada se centró en la trascripción de la colección diplomática de Quesada, que salvó de su destrucción (Carriazo Arroquia 1977: 26; Polaino 1972: xxxiii), cuando se trataba de hacer pasta de papel con los documentos, descubriendo "un lote de importancia de documentos de la Edad Media" (AGA 21/20.417). De su trabajo con las actas capitulares de Quesada, años después publicó $L a$ guerra de los moriscos vista desde una plaza fronteriza (Carriazo Arroquia 1947b) y su Colección Diplomática de Quesada (Carriazo Arroquia 1975: xiii), donde comenta que "cierto día del año 1938 (...) encontré todos los documentos del archivo amontonados y revueltos en la sala capitular, con el gran balcón abierto y con palas a mano para verterlos en unos camiones que se esperaban y los llevarían para hacer con ellos pasta de papel para periódicos. Pude impedir el desastre, sacrificando Gacetas e impresos sin valor". Entre sus testigos menciona a Martín Corral García, sacerdote de Quesada.

Reabierta la Universidad de Valencia en enero de 1939, se reincorporó a la misma, pero 15 días después su quinta de 1920 fue llamada a filas, siendo declarado útil para servicios auxiliares de segunda clase, aunque como lo presuponía, ya había sido destinado, desde el 3 de enero de 1939, por su cargo de Secretario de la Subsección de Excavaciones del Consejo Central de Archivos, Bibliotecas y Tesoro Artístico, a permanecer buscando documentos medievales en los Archivos de Quesada, Úbeda, Baeza y Huelma de la provincia de Jaén, en misión de la Junta de Ampliación de Estudios, probablemente con ayuda de GómezMoreno desde Madrid, mientras su familia residía en Quesada, a la vez que se encargó de la vigilancia patrimonial en los principales municipios de la provincia. Cuando vivía en Jaén se quedaba a dormir en la casa del padre político de su hermano Ángel, Antonio Tobar Llarena, en la calle de Las Palmeras, mientras que en Úbeda a veces dormía en el Hotel del Condestable Dávalo (AGA 21/20.417).

Realizando esta labor, inventarió la documentación medieval en los archivos municipales de Baeza y Úbeda, los cuales protegió, no consiguiendo impedir que en los de Villacarrillo y Villanueva de la Reina sus archivos fueran destruidos para hacer pasta de papel y publicar periódicos, lo que sí logró impedir en Quesada. En sus actividades arqueológicas, realizó el descubrimiento y excavación de los Baños Árabes de Torres (Jaén), que salvo de su destrucción. También excavó una necrópolis visigoda en el Puente de la Cercada, sobre el Alto Guadalquivir, que fue después destruida. Se preocupó igualmente de restaurar la cámara sepulcral del Cerro de la Horca (Peal del Becerro, Jaén), Monumento Nacional (AGA 21/20.417). Respecto a su trabajo de las crónicas para Espasa-Calpe, también corrigió la pruebas de dos de ellas, El Victorial: Crónica de don Pero Niño, conde de Buelma, por su alférez Gutierre Diez de Games (Carriazo y Arroquia 1940a) y los Hechos del condestable Miguel Lucas de Iranzo (Carriazo y Arroquia 1940c).

Tres días antes de la llegada de los nacionales a Quesada, puso la bandera nacional en el Ayuntamiento de Quesada, a la vez que continuaba su labor de vigilancia patrimonial en la provincia, por lo que "visitando algunos yacimientos arqueológicos en las inmediaciones de Quesada le sorprendió la terminación de la guerra" (AGA 21/20.417), remitiendo una carta el nuevo Alcalde nacional de Quesada, el 18 de abril de 1939, en el que informa al Decano de la Facultad de Filosofía y Letras de Sevilla que el "Profesor Carriazo se encuentra en este su pueblo, viniendo desarrollando la actitud más patriótica" (Carriazo Rubio 2001: 27). No le fue fácil regresar a Sevilla y al menos hasta Córdoba, según Torres Balbas, "llegó a Córdoba en lo alto de un vagón, con la familia" (Gallego Rico 1995: 175-176).

\section{CONSEJO DE GUERRA Y PRISIÓN EN SEVILLA}

Regresó a Sevilla el 22 o 23 de abril de 1939, entregando declaración jurada para el Jefe del Servicio Nacional de Enseñanza Superior y Media el 24 de abril y presentándose oficialmente en el rectorado de la Universidad el 25 de abril (AGA 21/20.417). Sin embargo, la noche del 3 de mayo fue detenido por una denuncia (AGA 21/20.417; Gracia 2009: 124) y conducido a la 
prisión provincial el 9 de mayo, permaneciendo en la cárcel hasta el 14 de febrero de 1940 (Carriazo Rubio, 2001: 28 n. 54), durante más de 9 meses, humillante experiencia a la que nunca hizo referencia, siendo entre los catedráticos de arqueología el que sufrió una pena más dura.

En su causa se sumaron varios factores, estancia en Madrid cuando en teoría debía estar en Sevilla, que le impidió presentarse cuando comenzó su proceso de depuración. Ser una persona pública por dirigir el Instituto-Escuela de Sevilla, como ha señalado Algora (1996: 351), el principal centro de la Institución Libre de Enseñanza en Sevilla. Finalmente, haber desempeñado un cargo en el Consejo Central de Archivos, Bibliotecas y Tesoro Artístico durante la Guerra Civil.

Cuando se presentó el 25 de abril, desconocía que además desde el 18 de abril, la Comisión Superior Dictaminadora de Expedientes de Depuración ya había acordado su "separación definitiva del servicio y baja en el escalafón respectivo" (AGA 21/20.417).

El expediente contra Carriazo había arrancado en plena Guerra Civil, incoado el 18 de junio de 1937 por la Comisión Depuradora, presidida por Antonio de Gregorio Rocasolano.

La comisión dispuso de informes del Gobierno Civil de Sevilla, del Rector de la Universidad de Sevilla, del secretario de la Comisión, Candido González Palencia, procedente de la Universidad Central y del Servicio de Información Política y Militar (S.I.P.M.).

$\mathrm{El}$ informe del Gobierno Civil indica "buena conducta privada y profesional, católico y persona correcta pero vanidoso y pedante. Ha tenido relación con elementos de izquierdas y ha sido favorecido por los mismos. Tipo moderado de la Institución Libre de Enseñanza de mal ambiente en Sevilla por el cargo que ha desempeñado, agravado por las circunstancias en que hubo de posesionarse del mismo e incluso por el local en que ejercía sus funciones. Instrumento dócil de la Institución Libre de Enseñanza, por eso fue encargado de la dirección del Instituto-Escuela, creado en el Colegio de los Jesuitas (...) Vanidoso, pedante con los inferiores; servil con los que cree superiores o le conviene adular. En clase, muy solapadamente, hacía propaganda de izquierdismo. Iba con los niños del Instituto a pasearlos, con la mochila al hombre, sin fijarse en el prestigio del cargo" (AGA 21/20.417; Gracia 2009: 123).

Según el Rector de Sevilla, José Mariano Mota y Salado, lo considera "simpatizante con las izquierdas (...) de buena conducta moral y fiel cumplidor de sus obligaciones de su cargo" (AGA 21/20.417). Este informe del Rector figura como anónimo en el Archivo Histórico de la Universidad de Sevilla (Carriazo Rubio 2001: 27).
De acuerdo con el Secretario de la Comisión de Depuración, el conquense Candido Ángel González Palencia, antiguo seminarista, Catedrático de Literatura Árabe de la Universidad Central de Madrid desde 1927 y notable especialista bajomedieval, con libros como la Historia de la España Musulmana (1925) o Los mozárabes de Toledo, en los siglos XII y XIII (1926-30), por lo que conocía la trayectoria de Carriazo, señala es considerado "tipo clásico de la Institución Libre de Enseñanza. No ha actuado, que yo sepa en política activa ni ha hecho labor sectaria; pero ha convivido íntimamente con los elementos de izquierda mereciendo su protección y fue nombrado director del Instituto Escuela (en el antiguo Colegio de los Jesuitas) y director de las excavaciones de Itálica. De buena conducta personal y profesional.

El informe del S.I.P.M. lo define como "simpatizante con los elementos izquierdistas (...) es individuo de buena conducta moral y fiel cumplidor también de los deberes de su cargo".

Estos informes sirvieron para abrirle un pliego de cargos, al cual sólo Carriazo pudo argumentar un pliego de descargo a la Comisión de Depuración, dos años después, el 26 de octubre de 1939, mientras permanecía en la cárcel:

1) Simpatizante de izquierdas, frente al cual en el pliego de descargo, Carriazo argumentará que es "hombre de hogar y estudio al que no ha interesado nunca la política".

2) Simpatizante con los elementos izquierdistas, enfatizando Carriazo en su defensa que sólo reconocía "cierto platónico interés porque se mejore la condición de los humildes y se haga efectiva justicia social".

3) Tipo clásico de la Institución Libre de Enseñanza, precisando Carriazo en su descargo que "no he sido en ella profesor ni alumno".

4) Ha convivido íntimamente con los elementos de izquierda, indicando Carriazo que no saludaba ni trataba al diputado y catedrático de Instituciones del Derecho Romano, Wenceslao Roces Suárez. En la facultad sólo comía habitualmente con Jesús Pabón y Suárez de Urbina, diputado de derechas y con Diego Angulo Íñiguez, antiguo compañero suyo en el Centro de Estudios Históricos.

5) Ha merecido su protección, nombrándole director del Instituto-Escuela y director de las excavaciones de Itálica. Sobre ambos cargos precisa Carriazo que fue director en el primero "por haber pertenecido al de Madrid y conocer el sistema, y por mi ponderación de carácter. En cuanto al nombramiento de las 
excavaciones de Itálica, lo hizo (creo que a propuesta de mi antecesor, el señor Conde de Aguiar, que estaba casi ciego) la Junta Superior de Excavaciones (...) considerándome la persona más caracterizada en investigaciones arqueológicas a la sazón en Sevilla".

6) Instrumento dócil de la Institución Libre de Enseñanza.

7) Hacía propaganda izquierdista en su clase, muy solapadamente, acusación que Carriazo considera "interpretación aviesa de un malvado", solicitando el testimonio de un antiguo alumno y Consejero Nacional del Movimiento, Pedro Gamero del Castillo.

8) No cuidaba el prestigio del cargo, acompañando a los alumnos del Instituto en expediciones como si fuera un ayudante, ante el cual Carriazo admite que hacía visitas con estudiantes españoles y extranjeros, pero "no entiendo bien este cargo" (AGA 21/20.417).

La Comisión Depuradora lo citó en Sevilla el 28 de junio de 1937, pero obviamente no pudo comparecer, por lo que la Comisión propuso su separación definitiva de servicio e inhabilitación para cargos directivos y de confianza. A ello se le sumó un informe del Gabinete de Censura del Cuartel General de Generalísimo Franco de 4 de junio de 1938 por haber firmado un escrito de protesta por los bombardeos de Barcelona. Y el 28 de julio de 1938 fue incluido en una requisitoria del Jefe de los Servicios de Archivos y Bibliotecas, contra dos funcionarios del Cuerpo de Archiveros y Bibliotecarios, José María Giner Pantoja y Teresa Andrés Zamora, contra el catedrático de Instituto Antonio Rodríguez-Moñino y contra Carriazo por "la participación en el despojo y ocultación de nuestro Tesoro Artístico, que han tenido en zona roja". Finalmente, la Comisión Superior Dictaminadora de Expedientes de Depuración ratificó el 18 de abril de 1939 su "separación definitiva del servicio y baja en el escalafón respectivo” (AGA 21/20.417).

Una vez detenido, el 3 de mayo se le abrió un Consejo de Guerra con Procedimiento Sumarísimo de Carácter Urgente, acusado de "delito de auxilio a la rebelión (...) al haber aceptado un cargo que revelaba confianza del gobierno rojo", teniendo que declarar ante el Juez Instructor y Comandante de Infantería, Ildefonso Pacheco Quintanilla. La sentencia del Juez Militar, presidida por el Coronel de Caballería, Arturo Cepo Rodríguez, consideraba probado que "estaba afiliado al partido político de Izquierda Republicana" y haber realizado "una aportación pecuniaria a favor de la institución llamada 'Estanislao del Campo', al parecer para contribuir a la realización de los fines benéficos de la misma", pero fue absuelto por haber desempeñado el cargo técnico del que era acusado, ser Secretario de la Subsección de Excavaciones del Consejo Central de Archivos, Bibliotecas y Tesoro Artístico, no probarse participación política alguna y valorarse positivamente su labor en Quesada y otros municipios de Jaén, declarando la sentencia el 12 de febrero de 1940 que le "absuelven del delito de que ha sido acusado (...) ordenándose su libertad", que se convierte en "sentencia firme y ejecutada" el 1 de marzo de 1940 (AGA 21/20.417; Gracia 2009: 123), si bien fue liberado desde el 14 de febrero de 1940 (Carriazo Rubio 2001: 28 n. 54).

Carriazo, aunque nunca realizó actividad política en público, pertenecía a Izquierda Republicana de Manuel Azaña, como ya había indicado su nieto, Juan Luis Carriazo Rubio (2001: 27 n. 42). El doctor Estanislao del Campo fue Catedrático de Fisiología Humana en la Facultad de Medicina y Rector de la Universidad de Sevilla entre 1931-34, cuando falleció prematuramente por tuberculosis con sólo 45 años, y como miembro del Partido Republicano Autónomo de Sevilla, dentro de la alianza de republicanos y socialistas, fue elegido concejal del Ayuntamiento de Sevilla en 1931. Debió ser una persona fundamental en la vinculación de Carriazo con los republicanos sevillanos, integrados desde 1934 en Izquierda Republicana.

Una vez absuelto, el Juez Depurador de Personal de Universidades del Ministerio de Educación Nacional, Arturo Caballero Segales, abrió procedimiento de información de personas próximas en la labor docente e investigadora de Carriazo, que fue claramente favorable. El informe más importante fue el Antonio Tovar Llorente, discípulo de Mergelina, Director General de Enseñanza Profesional y Técnica y Consejero Nacional del Movimiento, quien indicó el 11 de abril de 1940 que lo conoció en el verano de 1933, durante el Crucero del Mediterráneo, “con quien conviví durante algún tiempo, pudiendo asegurar se trata de persona absolutamente honorable y que no ha intervenido activamente nunca en política".

El Rector y Catedrático jubilado de la Universidad de Sevilla, José Mariano Mota y Salado, lo definió el 2 de abril como "persona de orden (...) y exactitud en el cumplimiento de sus deberes".

El Decano interino de la Facultad de Filosofía y Letras de la Universidad de Sevilla, Francisco Murillo Herrera, también el 2 de abril, lo consideró "modelo de funcionarios" y "prestigioso profesor".

Cayetano Alcázar y Molina, entonces interinamente Catedrático de Historia Moderna de España en 
la Facultad de Filosofía y Letras de la Universidad Central de Madrid, y cuya proximidad con el Ministro de Educación Nacional, pues procedía de la Universidad de Murcia, lo refleja su futuro nombramiento como Director General de Enseñanza Universitaria entre 194651, el 26 de marzo lo calificaba de "persona de toda solvencia científica y moral".

El Cura de Huesa (Jaén), Martín Corral García, que había sido sacerdote en Quesada en la Guerra Civil, y con el que colaboró en la catalogación de los archivos municipales de Quesada y Baeza, indicó el 16 de abril que iba regularmente a misa con su mujer.

Finalmente, el gerente de la Editorial Espasa-Calpe, Aurelio Díez Mathieu, informó sobre su labor editorial de preparación de la Colección de Crónicas Españolas durante la Guerra Civil, como razón de hallarse en Madrid y ausente de Sevilla cuando estalló la sublevación el 18 de julio de 1936 (AGA 21/20.417).

Todo ello propició que el Juez Depurador propuso al Ministerio el 14 de mayo de 1940 resolución favorable, que redactó el 20 de mayo y fue aprobada el 21 de mayo por el Director General de Enseñanza Superior y Media, José Pemartín Sanjuán (AGA 21/20.417; Carriazo Rubio 2001: 27-26; Gracia 2009: 123).

\section{LA CÁTEDRA DE HISTORIA ANTIGUA Y MEDIA DE ESPAÑA EN LA UNIVERSIDAD DE MADRID}

Después de haber sido depurado favorablemente en mayo, Carriazo firmó la Cátedra vacante de Historia Antigua y Media de España en la Universidad de Madrid (Carriazo Rubio 2001: 29), convocada el 17 de septiembre de 1940, que Claudio Sánchez-Albornoz y Menduiña había detentado desde 1920, por haberse exiliado. Sin embargo, a pesar de sus mayores méritos científicos y en antigüedad como catedrático en comparación con el candidato ganador, la plaza fue concedida a Carmelo Viñas y Mey, Catedrático de Historia Antigua y Media de España desde 1931 en Santiago de Compostela, transformada en Historia Media Universal en 1933, que había sido separado de su cátedra durante la Guerra Civil por los republicanos y fue rehabilitado en 1939.

Carmelo Viñas nació en Ciudad Real en 1898, estudiando Filosofía y Letras y Derecho en las Universidades de Barcelona y Madrid, donde se licenció y se doctoró con Estudios históricos acerca de Felipe II en 1918, a los 20 años. Opositó y ganó plaza en el cuerpo de secretarios de ayuntamientos en 1926, desempeñándolo en pueblos de Andalucía, Extremadura y
La Mancha, hasta que ganó la Cátedra de Santiago de Compostela en 1931. Su investigación se orientó hacia el estudio del colonato indígena en América y el régimen de la tierra en América y España entre los siglos XVI al XIX, con un significativo periodo de actividad científica entre 1924-28, dentro de una línea de trabajo del sindicalismo católico. Notable falangista, colaborador del Instituto de Estudios Políticos que dirigía Alfonso García Valdecasas, uno de los fundadores de Falange, Viñas había sido discípulo de Antonio Ballesteros Beretta, al igual que el Marqués de Lozoya, Director General de Bellas Artes. Su hermano, Antonio Viñas y Mey, Secretario General de la Universidad de Valencia, era miembro de la Asociación Católica Nacional de Propagandistas, a la que también pertenecían Lozoya y el Ministro de Educación Nacional, Ibáñez Martín. Simultaneó su trabajo en la universidad con los de Secretario del Instituto Balmes de Sociología del Consejo Superior de Investigaciones Científicas, creado en 1942, y de la Revista Internacional de Sociología desde 1943, centro y revista dirigidos por Severino Aznar, su principal valedor, que lo consideraba su sucesor en la Cátedra de Sociología.

Severino Aznar y Embid fue la persona clave en el acceso a la plaza de Viñas Mey. Nació en Tierga, Catalayud, Zaragoza, el 10 de febrero de 1870. Empezó Teología, que abandonó, continuando Filosofía y Letras y Derecho en la Universidad de Zaragoza entre 1883-93, doctorándose en Madrid en Derecho en 1911. Miembro de Acción Social Católica, del Grupo de la Democracia Cristiana, del Partido Social Popular, y fundador en 1917 de la revista La Paz Social, accedió a la primera Cátedra de Sociología de la Facultad de Filosofía y Letras de la Universidad de Madrid desde mayo de 1916 hasta su jubilación en 1940, a los 70 años. Encargado de un nuevo proyecto de reforma agraria desde 1936 por los alzados, después de unirse al general Mola en Navarra, fue Consejero Nacional de Trabajo en el primer Gobierno de Burgos y después Director General de Previsión. Justificó el decreto de unificación de Falange y tuvo una estrecha relación con el también aragonés, importante miembro del Opus Dei y Secretario General del Consejo Superior de Investigaciones Científicas, José María Albareda. Con la proclamación de la República en 1931 publicó un libro personal, Impresiones de un demócrata-cristiano. Falleció en Madrid el 19 de noviembre de 1959.

Por otra parte, se decidió desplazar a mediados del curso 1940-41 a Carriazo a impartir docencia en la Cátedra de Historia de España Antigua y Media de la Universidad de Valencia, según un escrito remitido 
por el Ministerio del 19 de febrero (AGA, 21/20.417). La decisión fue del Director General de Enseñanza Superior y Media, José Ma . Pemartín Sanjuán, que dirigía toda la política de depuración del Ministerio, hermano de Julián Pemartín Sanjuán, Vicesecretario General del Movimiento entre junio de 1938 y agosto de 1939 y miembro del II Consejo Nacional de Falange Española Tradicionalista y de las J.O.N.S. desde septiembre de 1939. No obstante, pudo reincorporarse a Sevilla al curso siguiente de 1941-42, y tras el calvario de la cárcel y la posterior depuración, la posibilidad de que abandonase la universidad ayudó a que recibiera un trato especial en la Facultad.

Como recoge su correspondencia con GómezMoreno en noviembre de 1941, "En todas partes, y sobre todo en la Universidad, mil atenciones y zalamerías" y en junio de 1942, "quienes aseguraban que yo no podría volver a esta Universidad no han salido buenos profetas: más vale así. Todo el mundo es buenísimo y amabilísimo. Y yo tan riguroso como siempre en lo que son mis deberes, y más cándido que nunca" (Carriazo Rubio 2001: 30-31).

\section{CENTRADO EN LA HISTORIA BAJOMEDIEVAL DEL SIGLO XV}

La estrategia de Carriazo durante su encarcelación entre 1939-40 y posterior desplazamiento a la Universidad de Valencia en el curso 1940-41 fue centrarse en la culminación de sus tres primeras crónicas que tenía contratadas en la Colección de Crónicas Españolas de Espasa Calpe, El Victorial: Crónica de don Pero Niño, conde de Buelma, por su alférez Gutierre Díez de Games (Carriazo Arroquia 1940a), Crónica de don Álvaro de Luna, condestable de Castilla, maestre de Santiago (Carriazo Arroquia 1940b) y Hechos del condestable Miguel Lucas de Iranzo (Carriazo Arroquia 1940c). Publicadas éstas estando aún en prisión, después se centró en la continuación de esta colección de crónicas entre 1941-46, Memorial de diversas hazañas. Colección de Enrique IV, ordenada por Mosén Diego de Varela (Carriazo Arroquia 1941), Crónica de los Reyes Católicos, por su secretario Fernando del Pulgar (Carriazo Arroquia 1943a y 1943b), que Ladero Quesada (2001: 135) considera su autor favorito, Historia del Emperador Carlos V, escrita por su cronista el magnífico caballero Pedro Mexía, veinticuatro de Sevilla (Carriazo Arroquia 1945), Crónica del Halconero de Juan II, Pedro Carrillo de Huete (Carriazo Arroquia 1946a) y Refundición de la Crónica del Halconero de
Juan II, por el obispo don Lope Barrientos (Carriazo Arroquia 1946b). Un detallado análisis de cada crónica ha sido realizado por Beltrán (2001: 98), pero como recuerda, su obra sobre "la cronística castellana del siglo $\mathrm{XV}$ es verdaderamente apabullante: del reinado de Juan II, editó por vez primera la versión completa castellana de El Victorial y todo el ciclo del Halconero, con su hasta ese momento inédita Refundición; publicó una versión fiable de la Crónica de don Álvaro de Luna, aportando la identificación de uno de sus autores, Gonzalo Chacón; y editó parcialmente y preparó el material imprescindible (descubriendo uno de los manuscritos capitales) para la igualmente inédita Crónica de Juan II de Álvar García de Santa María. Del reinado de Enrique IV, editó el Memorial de Valera y (...) los Hechos del Condestable Lucas de Iranzo. Del de los Reyes Católicos, dio a conocer por vez primera las crónicas de Diego de Valera y de Alonso de Santa Cruz, reeditando con mejoras definitivas las de Pulgar y Bernáldez".

No obstante, no abandonó la arqueología, como ejemplifica la excavación con Collantes de Terán, entre diciembre de 1948 y febrero de 1949, del tholos de Ontiveros en Valencina de la Concepción, con apertura de la puerta del dolmen el 23 de enero (Carriazo Arroquia 1961-62: 211-212, 219) y en particular la redacción de su trabajo más extenso sobre prehistoria, el capítulo de La Edad del Bronce en la Historia de España de Menéndez Pidal.

La colección de Espasa-Calpe sobre Crónicas Españolas quedó lamentablemente interrumpida por decisión editorial. Esta etapa de estudio de las crónicas medievales tuvo prolongaciones en la Crónica de los Reyes Católicos, por Alonso de Santa Cruz (Carriazo Arroquia 1951), que ya tuvo que editar en la Escuela de Estudios Hispano-Americanos. Siguió las Memorias del reinado de los Reyes Católicos, que escribía el bachiller Andrés Bernáldez (Gómez-Moreno Martínez y Carriazo Arroquia, 1962) y finalmente la Crónica de Juan II de Castilla, por Álvar García de Santa María (Carriazo Arroquia 1982a).

Su vinculación a la Escuela de Estudios Hispanoamericanos entre 1950-54, donde fue jefe de historiografía y de investigación no fructificó, renunciando "por incompatibilidad con su dirección" (Carriazo Rubio 2001: 32), que ocupaba entonces José Antonio Calderón Quijano, lo que le impidió volver a disponer de una plataforma para seguir publicando sus crónicas.

$\mathrm{Su}$ último trabajo en esta línea, la Crónica de Juan II de Castilla, fue publicada incompleta por la Real Academia de la Historia, pues sólo cubre de 140611, faltó el periodo entre 1411-19 de la primera parte y 
toda la segunda que abarca entre 1420-34, y además carece de la introducción de Carriazo. Y ello a pesar de que González Jiménez (2001: 119-120 n. 23) vio el manuscrito original en dos carpetas en casa de Carriazo en 1979, el propio Carriazo (1952: 489) lo considera "el texto más importante de la historiografía castellana del siglo XV" en un estudio preliminar de esta obra y estaba trabajando en ella desde los años cuarenta (Carriazo 1946c), cuando publicó las noticias inéditas sobre la conquista de Canarias, y ya entonces comentaba, en la Crónica del Halconero de Juan II (Carriazo Arroquia 1946a: x), que la tenía "transcrita y en estudio muy avanzado".

Paralelamente a su trabajo con las crónicas, Carriazo se centró en el estudio de la frontera de Granada, con artículos aparecidos entre 1946-48 (Carriazo Arroquia 1946d, 1947b y 1948), que continua aspectos tratados en la introducción de los Hechos del condestable Miguel Lucas de Iranzo (Carriazo Arroquia 1940c), un personaje desterrado desde la Corte a la ciudad de Jaén, junto a la frontera del reino de Granada.

A partir de entonces y hasta 1958, el año del descubrimiento del tesoro de El Carambolo, la mayor parte de su investigación se centró en su "capítulo" de 529 páginas sobre la Historia de la guerra de Granada, aparecida años después en la Historia de España de Ménendez Pidal (Carriazo 1969b), cuya redacción Ladero Quesada (2001: 129) considera que concluyó hacia 1960.

\section{EL SERVICIO NACIONAL DE EXCAVACIONES ARQUEOLÓGICAS Y EL INTENTO DE CONTINUAR LAS EXCAVACIONES DE ITÁLICA}

A pesar de detentar Carriazo la Cátedra de Historia de España Antigua y Medieval en Sevilla, Martínez Santa-Olalla optó durante el periodo 1939-55 por nombrar a otros responsables arqueológicos en las provincias del distrito universitario. Con ámbito provincial, eligió a Francisco Collantes de Terán para Sevilla y a Carlos Cerdán Vázquez para Huelva, y como responsables locales a María Josefa Jiménez Cisneros en Cádiz y Samuel de los Santos Jener en Córdoba.

Las excavaciones de Itálica fueron encargadas desde 1937, en plena Guerra Civil, a Francisco Collantes de Terán y Delorme. Era una persona favorable al levantamiento militar, hijo del antiguo Rector y Catedrático de Latín de la Universidad de Sevilla, Antonio Collantes de Terán y Martínez, que en 1936 pasó a ser ArchiveroBibliotecario del Ayuntamiento de Sevilla donde había ingresado en 1924 y desde 1938 hasta 1969, en que se jubiló, Archivero-Jefe.

Las actuaciones inicialmente se centraron en 1937 en la restauración de algunos de los mosaicos como el de Hércules, otro con decoración geométrica y uno con la cabeza de Medusa del triclinio y un cubicula de la Casa de Hylas (Collantes, 1941: 237 fot. 1), donde participaron especialistas italianos enviados por la Italia de Mussolini (Luzón 1999: 160).

Al acabar la Guerra Civil comenzaron verdaderas excavaciones que recibieron apoyo de la Diputación Provincial de Sevilla y después de la Comisaría para la Conservación del Tesoro Artístico de la VI Zona, correspondiente a Andalucía Occidental, además del dinero de las entradas que servía para mantener la limpieza del yacimiento. Estas excavaciones en 1939 abarcaron el espacio entre la Casa de la Exedra y la muralla, como puede apreciarse entre los planos de Carriazo (1982b: 45 fig. 3) y de Collantes (1941: 236), en “el triángulo comprendido entre la primera decumana de la izquierda, la muralla y el (...) trozo del cardo, habiéndose hallado restos de edificaciones muy destruidas" (Carriazo 1982b: 47 fig. 8; Collantes 1941: 237 fot. 2).

En 1940 se ampliaron las excavaciones a la Casa de los Pájaros, de 32 x 52 m., situada "entre la tercera y la cuarta decumana de la izquierda, cuya fachada principal se abría al cardo" (Collantes 1941: 237), donde sólo se habían excavado previamente los mosaicos como el de la cabeza de Baco por el Conde de Aguiar. Ese año, el 5 de noviembre de 1940, se localizó una estatua de Afrodita desnuda, denominada "Venus" de Itálica (Collantes 1941: 237).

Como puede apreciarse, estas campañas de 1939 y 1940 continuaron la estrategia de trabajo planteada por Carriazo, de seguir excavando en superficie el yacimiento, unificando sectores y completando la excavación de las "casas" en las que sólo se habían descubierto por el Conde de Aguiar las zonas con mosaicos.

En las partidas presupuestarias que solicitó para excavaciones Martínez Santa-Olalla al Ministerio de Educación Nacional, en 1940 figura Itálica en el segundo escalón de importancia, a nombre de Collantes de Terán, con 20.000 pesetas, sólo superada con 30.000 pesetas para Mérida y con el mismo nivel que Clunia, que dirigía Blas Taracena, o Azaila por Juan Cabré (Gracia 2009: 267 tabla), dineros que no se concedieron. También figuraba en la partida de excavaciones de 1941, con el tope máximo de financiación en 15.000 pesetas, codirigidas por Collantes de Terán y José María Mañá de Angulo, miembro de Falange, igualándose a Mérida, Medina Azahara, Mesas de Asta, Clunia 
y la Cueva de la Pileta que dirigía Giménez Reyna. Significativamente, cuando se tuvo que reducir la partida económica de todas las excavaciones, sólo se mantuvieron con 15.000 pesetas, Mesas de Asta que codirigía Martínez Santa-Olalla, la Cueva de la Pileta e Itálica (Gracia 2009: 268 tabla, 270 tabla), pero estas nuevas partidas tampoco se concedieron. Itálica ya no figura en los dineros que sí empezaron a hacerse efectivos a partir de 1942, pero como puede observarse, las partidas previstas para 1940 o 1941, 20.000 y 15.000 pesetas, no superaban a las que ya había dispuesto Carriazo en 1934 y 1933 respectivamente, a pesar de la inflación después de la Guerra Civil.

Además de su Cátedra de Historia Antigua y Media de España, Carriazo tuvo como acumulada la docencia de la Cátedra de Arqueología, con seguridad los cursos 1950-51, 1951-52, 1952-53, 1953-54 y 1954-55, la Cátedra de Historia General de la Cultura Antigua y Media esos mismos años y la Cátedra de Prehistoria y Etnología al menos los cursos 1961-62 y 1963-64, siendo finalmente Catedrático de Prehistoria e Historia de España en las Edades Antigua y Media hasta su jubilación en 1969 y catedrático de primera categoría desde 1963 (AGA, 21/20.417), Cátedra de Prehistoria que retomó Manuel Pellicer Catalán entre 1985-1992.

El nombramiento de Carriazo como Delegado de Zona del Servicio Nacional de Excavaciones del Distrito Universitario de Sevilla le permitió volver a asumir la investigación arqueológica a partir de 1956, por su función de inspector, realizando diversas actuaciones sistemáticas y de urgencia (Carriazo Arroquia 1964 y 1966). Consciente de su insuficiente preparación como arqueólogo de campo, tras un parón de 20 años, entre 193656 , no dudó en solicitar la ayuda de Maluquer para El Carambolo o de Raddatz en Carmona cuando tuvo que afrontar estratigrafías complejas, además de contar con la regular colaboración de Collantes de Terán.

Ese verano de 1956 solicitó una bolsa de viaje a la Universidad de Sevilla para pasar dos meses en París y Londres y trabajar en archivos, bibliotecas y estudio de las "técnicas de excavación", entre el 15 de julio y el 15 de septiembre de 1956. Una segunda estancia de 15 días la realizó en París del 1 al 15 de junio de 1960 (AGA, 21/20.417).

Desde 1956, Raddatz y Carriazo comenzaron la excavación del santuario de Mulva (Villanueva del Río y Minas, Sevilla), la antigua Munigua, ocupada desde el siglo I a.C. hasta el siglo VII d.C., financiada por el Instituto Arqueológico Alemán de Madrid.

En la primavera de 1959, Raddatz propuso a Carriazo también excavar Carmona, pagando la actuación el
Instituto Arqueológico Alemán (Carriazo y Raddatz 1960: 342, 346 n. 1), mientras Carriazo estaba esperando recibir una beca de la fundación Juan March para reanudar las excavaciones en El Carambolo. La excavación se desarrolló del 6 al 25 de abril de 1959, con "pocos medios y escaso tiempo" (Carriazo y Raddatz 1960: 346, 350). Se seleccionó el lugar por la presencia de muros y huellas de fuego en un perfil de $200 \mathrm{~m}$. (Carriazo y Raddatz 1960: 349-350). Se abrió un corte de $9 \mathrm{~m}$. de extensión y $5 \mathrm{~m}$. de profundidad (Carriazo y Raddatz 1960: fig. 1), que al profundizar se centró en un espacio al interior de los muros $\mathrm{B}$ y $\mathrm{C}$, de algo menos de $3 \mathrm{~m}$., siguiendo niveles artificiales durante toda la excavación, que luego fueron unificados en 5 niveles (Carriazo y Raddatz 1960: fig. 2). Los estratos por encima de los muros, de casi $2 \mathrm{~m}$., estaban revueltos y no se estudiaron (Carriazo y Raddatz 1960: 350). El material recuperado fue depositado en la Universidad de Sevilla para que posteriormente pasase al Museo Arqueológico de Sevilla.

En colaboración con Collantes de Terán inició la excavación de El Carambolo Alto en 1958 (Carriazo Arroquia 1959) y el estudio del tesoro de Ébora en Sanlúcar de Barrameda en 1959 (Carriazo Arroquia 1970b), descubierto por los hijos de la Condesa de Lébrija, con lazos familiares con Mergelina. Ese mismo año de 1959 excavó el dolmen de Hidalgo y los silos de la Loma del Agostado (Sanlúcar de Barrameda, Cádiz) (Carriazo Arroquia 1975: 327, 332), el poblado de El Carambolo Bajo entre 1959-61 (Carriazo Arroquia 1970a y 1973), acordando con GómezMoreno la denominación de la cerámica como "retícula bruñida" (Carriazo Arroquia 1977: 40), la reexcavación del tholos de La Pastora en 1961 (Carriazo Arroquia 1974/1980: 146-147), el dolmen de Cañada Real en 1967 (Carriazo Arroquia 1974/1980: 153) y el campo de "silos" de Puebla del Río en 1965, donde excavó 81, de casi 200, entre febrero y marzo de 1965 (Carriazo Arroquia 1974/1980: 160-161).

No obstante, no olvidaba Itálica, cuya dirección fue una de las acusaciones que recibió en 1937. En la reunión de la Junta Consultiva del Servicio Nacional de Excavaciones Arqueológicas, de abril de 1957, en la que participaban Luis Pericot, Antonio García y Bellido, Antonio Beltrán, Carlos Alonso del Real, Cayetano de Mergelina, Carriazo, Elías Serra Ràfols -ausente- y Francisco Abad Ríos, Catedrático de Historia del Arte de la Universidad de Oviedo, se aprecia que los más influyentes eran Pericot y García y Bellido, quienes solicitaron una subvención más elevada, de 70.000 pesetas cada uno, de un total de 450.000 pesetas, un $15 \%$ 
cada uno. En esta reunión, Carriazo pidió 25.000 pesetas para reanudar las excavaciones de Itálica, lo cual se le rechazó por considerar sus miembros que era mucho dinero y sobre todo porque García y Bellido pidió ser codirector de las excavaciones dentro de un equipo donde también serían codirectores Carriazo, Collantes de Terán, Fernández-Chicarro - alumna de García y Bellido y aún no directora del museo hasta 1959- y Tarradell, requisito de un equipo e imposición de un codirector que sólo se le obligaba a Carriazo, a lo que se negó y renunció a continuar la excavación y a la subvención solicitada (ASO, 4-1957). La no continuación de las excavaciones "nos valieron reproches y reticencias que hubo que aguantar en silencio, porque detestamos las polémicas" y las actuaciones hubieron de "limitarse a trabajos de conservación y a pequeñas exploraciones, como la localización del teatro, que así pudieron excavar nuestros continuadores" (Carriazo 1982b: 35).

García y Bellido ya había actualizado en 1955 el plano de las excavaciones de Carriazo, añadiéndole las actuaciones de Collantes de Terán entre 1939-40 y al año siguiente, en 1958, realizó una pequeña cata en el interior de la Casa de la Exedra, autorizado por el Director General de Bellas Artes, Gallego Burín, que le sirvió para justificar la publicación del libro Colonia Aelia Augusta Italica (García y Bellido 1960), antes de que Carriazo publicase los resultados de sus campañas de excavación de 1933-35.

Con la llegada de Nieto Gallo a la Dirección General de Bellas Artes en 1961, el dinero se continuó transfiriendo a las excavaciones en Madinat al Zahrâ' en Córdoba, política que apoyó activamente Nieto Gallo con la compra de terrenos y la restauración del yacimiento por los arquitectos Félix Hernández y Basilio Pabón (Nieto Gallo 1964a: 60; Carriazo 1982b: 35-36).

La relación entre Carriazo y García y Bellido después de la oposición de la cátedra de 1931 nunca se recuperó y se refleja en las actas del VII Congreso Nacional de Arqueología, celebrado en Sevilla en 1963, pues Carriazo acusó a García y Bellido (1960) de utilizar sin citarlo el plano de Itálica en el libro Colonia Aelia Augusta Italica, concretamente "pirateados a mansalva con desconocimiento de la propiedad intelectual", el cual fue el primero en realizarse en 1935, después de sus campañas de excavación entre 1933-35, exponiéndolo en el Museo Arqueológico de Sevilla. Por el contrario, García y Bellido (1964: 459-460), que había realizado una pequeña cata en 1958 en el interior de la Casa de la Exedra, consideraba que "el plano por mí publicado y firmado en Itálica en 1955, está hecho por mí sobre las ruinas mismas, buscando y rebuscando en ellas los más débiles trazos de obra; está todo medido por mí personalmente, y todo dibujado por mi propia mano".

Este plano de Itálica lo perdió Carriazo después de la Guerra Civil, antes de mayo de 1941, "plano que por entonces nos daba grandes enojos, porque algunos para hacerse con él, manu militari, no dudaban ni en poner en riesgo la propia vida", según críptica descripción del propio Carriazo (1982b: 40).

De la Casa de la Exedra ya presenta un plano detallado el propio Carriazo (1935: 307), acompañado por una reconstrucción ideal de la Casa de los Pájaros, con dibujo de Francisco Collantes (Carriazo 1935: lám. $2 / 2$ ), y otro plano muestra el trazado de la muralla excavada en 1935, muy próxima a la Casa de la Exedra (Carriazo, 1982b: 45 fig. 3). También pensó escribir su discurso de ingreso en 1958 en la Real Academia de Bellas Artes de Santa Isabel de Hungría en Sevilla (Carriazo 1960/1978: 56-57) sobre el "Urbanismo de Itálica", que nunca materializó.

El descubrimiento de El Carambolo desvió su atención de Itálica como el mismo reconoce, "Menos mal que otras labores, como la excavación de El Carambolo (...) nos compensaron con largueza" (Carriazo 1982b: 36) de no retomar las excavaciones de Itálica. Incluso el propio García y Bellido, como reconocía Carriazo (1964/1978: 21), en la reunión de la Junta Consultiva del Servicio Nacional de Excavaciones Arqueológicas de 1959, señaló en la Junta que "A la vista de estos materiales tenemos que rehacer una parte de la Prehistoria española".

\section{ANTES DE EL CARAMBOLO: LOS ORÍGENES CALCOLÍTICOS DE TARTESSOS}

En su futura propuesta de Tartessos, Carriazo siguió las líneas trazadas por Gómez-Moreno, retrotrayendo sus orígenes al Calcolítico hasta su apogeo durante el Bronce Final III, paralelo a los inicios de la Edad del Hierro en el Mediterráneo Oriental, durante el periodo geométrico, enfatizando la importancia del sustrato autóctono.

Para Gómez-Moreno, Los Millares, pudo ser "metrópoli de colonizaciones por mar remotísimas", teniendo algunas de sus vasijas incisas y pintadas "alguna similitud con las del Egipto prehistórico". Estos orientales, a quienes denomina "tartesios o túrdulos" por el territorio peninsular que ocupaban, especialmente el "Mediodía, en donde radicó su máximo apogeo", coexistirían con las poblaciones precedentes contra los que inicialmente, en "la costa oriental" o Sureste, "primera base quizá de sus establecimientos, 
hubieron de oponer murallas formidables a las asechanzas de los indígenas". Ellos aportarían el conocimiento de la metalurgia pues "no era posible los adivinasen nuestros míseros aborígenes paleolíticos por su sólo esfuerzo intelectual, y mucho menos la aleación constitutiva del bronce", pues coexistirán ambos como planteaba L. Siret, y su escasez se debería al posterior descubrimiento de las fuentes de estaño del Noroeste, "dando lugar a un periodo en que éste predomina".

Ellos serían los encargados de difundir "a través de los mares del Norte" la neolitización, el megalitismo, la metalurgia y el vaso campaniforme, que denomina "cerámica tartesia", en "expediciones tartesias, que llevarían un fin comercial, acaso en connivencia con los fenicios", siguiendo las premisas de L. Siret nuevamente, a "la busca del ámbar" báltico y "beneficiando las minas inglesas de plomo y estaño", lo que les obligaría a instalar alguna "base" a la vez que estarían "adiestrando siempre y por doquier a los indígenas" (GómezMoreno 1908: 88-89, 92 y 1924: 317).

En La novela de España amplió estas valoraciones. En "la Edad del Cobre, mal llamada período eneolítico por los prehistoristas" (Gómez-Moreno 1928/1974: 419), sucede una fuerte influencia del Mediterráneo Oriental que identifica con Tartessos. "La tradición habla de un estado de cultura vetustísimo entre los tartesios de España, con poemas y leyes; habla del disfrute por los occidentales de una felicidad y riqueza envidiables (...) y también de sus empresas náuticas (...) por el océano, comerciando con las islas Británicas y hasta Germania" (Gómez-Moreno, 1928/1974: 419). Su origen era oriental, "Arqueológicamente comprueban la proveniencia oriental de dicha cultura ciertas afinidades muy precisas con lo primitivo de Egipto, en culto funerario, amuletos, cerámica, tipos industriales de piedra, cobre y oro, uso de tintes y perfumes, ciertas piedras finas, cultivo de cereales, tejidos de lino (...) en el territorio tartesio, con su centro en Andalucía, corriéndose para abarcar las cuencas del Segura y del Tajo, hasta las fuentes de este último, con más expansiones costeras por el océano, hasta el Pirineo, y otras africanas. Su fuerza comercial pruébase con la existencia de piezas industriales nuestras en Bretaña e Inglaterra; y, a la inversa, vemos cuentas hechas con ámbar del Báltico, enseres de marfil, huevos de avestruz, etc., en estaciones tartésicas" (Gómez-Moreno 1928/1974: 420).

Los monumentos más representativos serían "los gigantescos monumentos megalíticos, a cuya cabeza está la cueva de Menga en Antequera, y cuya imitación, ruda y mezquina, son los campos de antas, o sea, dólmenes de las zonas periféricas, débilmente influidas por lo tartésico y atrasadas en su industria”, rechazando el origen portugués del megalitismo defendido por Bosch Gimpera en su Cultura Occidental Megalítica o Cultura Megalítica de Portugal, con proyección en el Norte de Castilla-León y Cordillera Cantábrica (Bosch Gimpera 1915-20: 518-519, fig. 192 y 1920: 148-155), indicando que "un evolucionismo estrecho y anticuado, hacen buscar su origen en regiones españolas pobres y bárbaras, sin considerar que su primitivismo es grosería" (Gómez-Moreno 1928/1974: 421).

Sin embargo, los lazos que inicialmente existían con el Mediterráneo Oriental se acabaron cortando, "la disparidad progresivamente acentuada respecto del Mediterráneo oriental, prueba su aislamiento, sólo explicable si los tartesios no navegaban por este mar ni los orientales llegaban normalmente a nuestros confines. El auge de esta civilización occidental podría calcularse hacia el siglo xxvi [2600-2500] antes de Cristo" (Gómez-Moreno 1928/1974: 420-421).

Durante "el tercer milenio a. de C. es cuando podemos justificar la llegada de estos nuevos orientales a nuestros confines, navegantes del Egeo, traídos por (...) la riqueza minera del litoral andaluz y especialmente su cobre, en Sierra Almagrera (...) Allí mismo, en el cabezo de Almizaraque, es donde subsisten vestigios de la que pudo ser primera mansión de navegantes egeos (...) su avance hacia el interior viene marcado por (...) los Millares (...) hasta Granada y Antequera de paso para aquel 'Jardín de las Hespérides', que es la Andalucía baja regada por el Betis". "Su procedencia oriental es indudable; ya porque traían aquel grado de cultura sedentaria y de experiencias metalúrgicas, obtenidas en Asia y desarrolladas en Egipto, ya por un avance en sentido espiritualista, respecto al estado neótico, que se cifró en dotar de casa al difunto para mejorarle la vida de ultratumba (...) conchas del mar Rojo, según se dice; unas cuchillas de pedernal, de tipo egipcio primitivo; la muy notable vajilla, grabada y enyesada, con precedentes egipcios también (...) peines de marfil, etc. Todo ello no resulta con más avances que los obtenidos bajo las primeras dinastías faraónicas" (Gómez-Moreno 1958: 96-97).

Pronto, "la Baja Andalucía regada por el Betis, fue centro tartesio por excelencia". "Tartesos (...) abarcó todo el mediodía peninsular, desde la desembocadura el Tajo hasta la del Segura, sin penetrar mucho hacia la Mancha (...) su organización en reino, único en todo el Occidente, justificando por sí sólo un entronque oriental de altura; también, su riqueza, generosidad y pacifismo; también, la antigüedad milenaria de su cultura, con leyes en verso, $y$, desde luego, la implantación de una escritura 
vetustísima (...) Andalucía, por sus propios recursos, habíase constituido en una sociedad integral, casi perfecta". El "poderío tartesio, esencialmente pacífico e industrioso, base de comercio marítimo sin competencia a través del Océano (...) Progresaron así las naves tartesias hasta descubrir las Islas Británicas y el báltico". "Franca para los tartesios la navegación por el Atlántico y alcanzados por sus naves los dos países septentrionales más asequibles, Irlanda y Bretaña, se entablaron relaciones comerciales, de que son testimonio el susodicho acervo de cerámica, oro y cobre (...) y en prueba de ello tenemos una gran agricultura sepulcral, con ejemplares de tipo de cúpula y callejón largo muy degenerado". Los dólmenes fueron "otra manifestación de la propaganda tartesia en los países septentrionales, sin precedentes allá, pero bien documentada en Andalucía" (GómezMoreno 1958: 97, 103, 105, 111, 113).

Otro defensor de esta tesis fue Hernández Pacheco (1959: 222-223), ya entonces jubilado, pero también contemporáneo de Gómez-Moreno pues había nacido en 1872. Según él, "El reino de Tartesos comenzaría al empezar el eneolítico y ejercería influjo cultural (...) especialmente hacia el Este en la época del bronce, de tal modo que la cultura del Argar en lo que presenta la autóctona serie [sic, de autóctona sería] de origen tartesio". "El gran desarrollo de los Tartessos fué debido principalmente a la riqueza minera del país, base de su comercio con el Oriente mediterráneo: el cobre, el plomo y la plata estaban en la parte occidental del país o muy cerca, en Sierra Morena; el estaño y el oro en los aluviones de la mitad occidental de la Península".

Ambas propuestas son notablemente diferentes al modelo planteado por Schulten (1945: 9, 13-14) quien consideraba Tartessos "la primera ciudad comercial y el más antiguo centro cultural de Occidente", pero fruto de la arribada de poblaciones del Mediterráneo Oriental durante el Bronce Final. "Esta ciudad fué fundada después [d]el año 1200 a. de J.C., por los Tirsenos del Asia Menor, los ancestrales de los Etruscos itálicos, en la desembocadura del Guadalquivir, y se llamó Tursa o Turta, es decir, 'ciudad de los Tirsenos', nombre que los Fenicios transformaron en 'Tarschisch', los griegos en 'Tartessos'. Esta ciudad creó un gran imperio, que comprendía toda la España meridional. Era un organismo estatal perfectamente organizado, que poseía no sólo su agricultura, su minería, su industria, su comercio ultramarino, sino también una elevada cultura intelectual, productora de antiquísimos anales, epopeyas y leyes".

Los planteamientos de Gómez-Moreno fueron seguidos por Mergelina (1920 y 1922) y Carriazo, quien indica que "el maestro Gómez-Moreno y, siguiéndole, algunos de sus discípulos, adoptamos como hipótesis de trabajo la identidad de Tartesos con la gran cultura eneolítica de la Baja Andalucía (...) Nuestra hipótesis de trabajo pasó sin pena ni gloria" (Carriazo Arroquia 1973: 53) al no recogerla ni Bosch Gimpera ni Obermaier.

Así, cuando estudió los ídolos-cilindros del calcolítico (Carriazo 1931a: 97, 110), son clasificados como "La escultura tartesia", considerando que en la etapa "Eneolítica o, lo que es lo mismo, pero mucho mejor, tartesia (...) todos los trabajos posteriores confirman, directa o indirectamente, el acierto de la ecuación Tartessos=Eneolítico".

En el caso de Carriazo, sólo en el momento del descubrimiento del tesoro de El Carambolo en 1958 le entraron dudas sobre la vinculación del megalitismo calcolítico con Tartessos. "Creo que de ahora en adelante las cosas estarán más claras, simplemente con dejar el Eneolítico a unos pretartesios (el nombre es de Schulten) y atribuir a los tartesios protohistóricos, o a sus continuadores turdetanos, nuestra nueva cultura de El Carambolo" (Carriazo Arroquia 1960/1978: 69).

Sin embargo, pronto retomó las tesis defendidas por Gómez-Moreno que tanto se diferenciaban de Schulten. "Los orígenes de Tartessos se hunden el II milenio antes de Jesucristo, pues su existencia es el supuesto previo de la fundación de Cádiz. Su florecimiento ocurre entre el siglo IX y el siglo V, con el apogeo en el siglo VII". "La cultura de Tartessos es el caso particular hispánico de ese fenómeno general de la cuenca mediterránea que es el estilo geométrico. Una cultura que en el área griega, donde está mejor conocida, no tiene precedentes, pero en Andalucía sí, y copiosísimos; toda la decoración geométrica del vaso campaniforme, de la pintura esquemática andaluza, de los ídolos-placas e ídolos-cilindros". "La nota esencial de los materiales del Carambolo es su indigenismo. Casi todos estos materiales se enlazan con los de las civilizaciones eneolíticas del Bajo Guadalquivir, y luego se enlazan entre sí, como para demostrar que son autóctonos" (Carriazo Arroquia 1969: 339-340).

Es interesante observar que aunque admite el carácter calcolítico de los enterramientos en tholoi, presupone su continuidad durante la Edad del Bronce, que apoya en los tholoi micénicos, "Tartessos (...) En las cercanías de la ciudad habrían de estar las tumbas de sus viejos reyes, grandiosos edificios copulares como los de Antequera, que son compañeros en Occidente de las tumbas regias de Micenas y Orcomenos. ¡Cuantos tesoros no habrá en esos sepulcros!" (Carriazo Arroquia 1960/1978: 69). 
Dentro de estas premisas, conviene encuadrar las intervenciones que realizaron Carriazo y Collantes de Terán en 3 de los dólmenes calcolíticos más importantes del conjunto de Valencina de la Concepción, los de La Pastora, Matarrubilla y Ontiveros, a partir del descubrimiento de este último en 1948. No en vano, uno de los temas sobre los que pensó escribir su discurso de ingreso en 1958 en la Real Academia de Bellas Artes de Santa Isabel de Hungría en Sevilla (Carriazo 1960/1978: 56) era la "Arquitectura dolménica", deteniéndose en el estudio del dolmen de Ontiveros.

Es llamativo que Maluquer (1960: 275) primero se distancie de la propuesta de Gómez-Moreno cuando señala que "Para algunos la civilización tartésica quedaría reflejada en la gran cultura megalítica, como opina Gómez Moreno (...) Tal identificación corresponde ciertamente a la alta antigüedad que la tradición oral recogida en último término por Estrabón atribuía a la cultura turdetana del bajo Guadalquivir", aunque considera que Tartessos sólo "puede ceñirse entre poco antes del año 1000 y el 500 a. J.C.".

Pero con el paso de los años, este Tartessos cuyos orígenes se remontaban al Calcolítico, es recogido en el Tartessos de Maluquer (1970), aunque ya no cita a Gómez-Moreno que acababa de morir, y también ahora retrotrae los inicios de la civilización occidental al Calcolítico hasta constituir un gran Estado en el Bronce Final, modelo que subyace en distintos autores hasta la actualidad.

Según Maluquer, “Algunos de los grandes sepulcros megalíticos de Andalucía, como la cueva de Menga, por el enorme esfuerzo constructivo que representa, sugiere la existencia de un poder concentrado, ordenado del trabajo, con dominio sobre abundante mano de obra libre o servil. Las tumbas andaluzas semejan verdaderas tumbas principescas" (Maluquer 1970: 28).

Durante la Edad del Bronce, se produce "la aparición en toda la cuenca del Guadalquivir y en el borde meridional de la Meseta, de jefes y reyezuelos en diversos grupos tribales que imitan a los jefes de las ciudades costeras y aún les superan en boato y riqueza. Símbolos de este poder individualizado serán las diademas que hallamos en Montilla (Córdoba), en la cueva de Los Murciélagos (Albuñol, Granada)". "En el transcurso del segundo milenio la evolución social y política se ha completado, y de los principados se pasa a la monarquía urbana en la cuenca baja del Guadalquivir y en las zonas costeras. En el interior se conservará un régimen de monarquía principesca de tipo señorial. Ambas quedarán reflejadas en la legendaria mitología del reino de Tartessos" pues "Tartessos, como todas las grandes monarquías mediterráneas, tiene también sus dinastías divinas, míticas" (Maluquer 1970: 30, 32, 37).

Este proceso culminará hasta constituir un Estado de dimensiones descomunales durante el Bronce Final, "a partir del reinado de Habis la característica esencial del Estado tartésico es su estructura urbana. En esencia corresponde al tipo de monarquía que predomina durante el segundo milenio en las orillas orientales del Mediterráneo, costas sirias, isla de Chipre, etc.". "Lo que sorprende de Tartessos y que no permite ajustar su monarquía al patrón de Ciudad-Estado, es que la autoridad de sus reyes y las actividades de sus súbditos alcanzaron en algún momento un territorio extensísimo, desde el Atlántico hasta el Mediterráneo, es decir, un territorio cuya organización tenía unas exigencias muy superiores a las de la mayor parte del de las ciudadesestado conocidas. También la actividad de sus súbditos era inmensa si tenemos en cuenta sus empresas mediterráneas hasta Cerdeña y sus navegaciones hasta las Casitérides" (Maluquer 1970: 50).

Durante el Bronce Final, Tartessos inició una expansión comercial transportando metales hacia el Mediterráneo Occidental, "con verdaderas expediciones dirigidas al establecimiento de puntos de comercio fijos. A esta orientación corresponde por ejemplo la fundación de la ciudad de Nora en Cerdeña. Norax, el rey de Tartessos, tomó la iniciativa, y es precisamente esa iniciativa trascendente la que marca el predominio de Tartessos sobre todos los restantes principados que existían en el sur. El centro político y económico se traslada del Sudeste a la cuenca baja del Guadalquivir", "coincide con el hundimiento del poder micénico en Grecia y será paralelo al desarrollo de la invasión doria en la zona del Egeo. La leyenda griega, al fijar la época de la fundación de Nora en tiempos del heráclida Hyllus lo confirma. Tartessos había hallado su camino antes de la aparición de los primeros fenicios" (Maluquer 1970: 53, 55).

Esta continuidad entre el megalitismo del Calcolítico como etapa formativa de un Tartessos con leyes de miles de años de antigüedad también la sugiere Collantes de Terán (1969: 61), colaborador habitual de Carriazo en la Delegación de Zona de Sevilla, mientras también se resalta la continuidad del megalitismo y el Argar hasta alcanzar la "cultura nativa" de Tartessos por Blanco y Rothemberg (1981: 171), que demostraría la tesis de Gómez-Moreno.

En cambio, otros autores como Tarradell (1969: 224) no consideraron apropiado "utilizar en el II milenio una denominación que, según los textos, se refiere a la primera mitad del primero", por lo que precisa que "No creemos lícito llamarla tartésica". 


\section{LA SUPUESTA INFLUENCIA DE LOS TARTESIOS DE ORIGEN CELTA INDOEUROPEO DE MALUQUER EN LA IDEA DE CARRIAZO SOBRE TARTESSOS}

En los últimos años se ha defendido por Álvarez Martí-Aguilar (2005: 228 y 2010: 72) que fue Maluquer, a partir de 1955 como "hito inaugural", quien "propone un nuevo modelo de interpretación de la personalidad histórica de Tartessos", considerando que su artículo sobre El Bronce Carriazo (Maluquer 1957: 167, 168 n. 26), antes del descubrimiento del Tesoro del Carambolo, "es el verdadero acta de nacimiento de la arqueología tartésica", al considerar que las manufacturas de bronce no eran de un taller de Gadir como sugerían Blanco Freijeiro y García y Bellido, sino tartésico. Esto le lleva a manifestaciones tan llamativas como "La forma en que Carriazo interpretó los célebres materiales de El Carambolo, desde su hallazgo en 1958, es buena prueba del éxito de las tesis de Maluquer" o que "Carriazo fue siempre el más fiel seguidor de la tesis de Maluquer" (Álvarez Martí-Aguilar 2005: 230). En esta línea acaba de considerar que Maluquer fue el "auténtico ideólogo de la investigación contemporánea de Tartessos" y "la ascendencia intelectual que el por entonces catedrático de Prehistoria de la Universidad de Salamanca mantiene sobre nuestro autor [Carriazo] es clave para comprender su interpretación de los futuros hallazgos de El Carambolo" (Álvarez MartíAguilar 2010: 68, 70). Esta propuesta creemos debe matizarse, en particular la influencia de Maluquer en los primeros años, previos y posteriores al hallazgo de El Carambolo.

Maluquer era un investigador centrado en la Edad del Hierro del Valle del Ebro y su prestigio procedía principalmente de las excavaciones en el Alto de la Cruz (Cortes, Navarra), del que acababa de publicar dos volúmenes (Maluquer 1954-58). Simultáneamente, estaba cada vez más interesado en la presencia de materiales orientalizantes en el interior de la Meseta, publicando también en 1958 las monografías sobre El Berrueco (Maluquer 1958a) y los Castillejos de Sanchoreja (Maluquer 1958b). Su artículo de 1955, El proceso histórico de las primitivas poblaciones peninsulares, es una propuesta general de desarrollo de la prehistoria peninsular, donde Tartessos sólo figura en la última página, en la cual sugiere que "Tartessos y sus reyes" son resultado del despegue del comercio de metales después de la crisis de los Pueblos del Mar del siglo XII a.C., "La reestructuración de los países del Mediterráneo oriental, después de los movimientos de los pueblos del mar y de la invasión doria en Grecia, hace necesario y posible el comercio de metal de occidente. Tartessos, como antes la cultura megalítica andaluza, hace de intermediario". No hay aparentemente razones para plantear un "hito inaugural" desde 1955.

Un segundo artículo más centrado en el tema es El bronce Carriazo de 1957. Se trata de una pieza que compró Carriazo en el mercadillo de antigüedades de Sevilla, "a unos gitanos que no hicieron de ella el menor aprecio", y para no publicarla él como procedente de su propia colección particular, la cedió a Maluquer, un buen amigo, como el propio Maluquer (1957: 157) reconoce, "nuestro querido amigo Juan de Mata Carriazo", que al consultarle su opinión probablemente ya la identificó como hallstática, un ámbito que no dominaba Carriazo.

La pieza atrajo el interés de Maluquer por considerar que fusionaba elementos hallstáticos con otros orientalizantes que define como tartésicos. "Teniendo en cuenta la interpretación de esos amuletos o pájaros barquiformes como símbolos de culto solar, la pieza que nos ocupa admite plenamente esa clasificación, pues posee, con excepción de la sustitución de la rueda por la diosa, todos los rasgos de esas piezas hallstáticas, incluso en el detalle de poseer anillas para cadenitas colgantes (...) En definitiva vemos que nuestra pieza realiza el perfecto simbolismo del mundo hallstático. La substitución de la rueda solar por la diosa de la fecundidad es una genial solución tartésica" (Maluquer 1957: 161-162).

La pieza la fecha en el siglo VI a.C., o 625-575 a.C., momento en que considera que el Suroeste, incluido Tartessos, esta ocupada por tribus célticas incineradoras. "Tartessos representa un elemento mediterráneo en contacto con un mundo celta del que en parte depende su propia economía (los metales). Que ese contacto no se limita a un mero intercambio aparece bien por un lado en las fuentes históricas, que nos muestran un sudoeste peninsular ocupado por tribus célticas ya en el siglo VI, y por otro la arqueología, que en Carmona [Cruz del Negro] nos lo confirma plenamente. Otros muchos argumentos podrían deducirse de la onomástica posterior, etc. El contacto de Tartessos con el mundo céltico a nuestro juicio es la premisa necesaria para su propia existencia. El comercio tartésico precisa tanto del comprador griego o fenicio como del productor y consumidor a la vez, celta" (Maluquer 1957: 166), es decir, los celtas de Tartessos producen, pero también consumen, estas manufacturas de bronce.

Las necrópolis de incineración de Cruz del Negro y de Setefilla también las fechaba en este siglo VI pues 
considera para "la necrópolis de Cruz del Negro o a las de Setefilla para las cuales una fecha alrededor de los siglos VI a.C. no parece desacertada" (Maluquer 1960: 292).

Esta interpretación del bronce Carriazo fue aceptada por su propietario, que no parece tener un criterio propio sobre el mismo (Carriazo Arroquia 1973: 677), y admite la presencia de un "sincretismo, en el que se suman temas iconográficos de tradición egipcia, elaborados en Chipre, con otros de la Europa central aportados por los celtas".

El aspecto más novedoso en el trabajo de Maluquer es reivindicar el nombre de tartésico para estas manufacturas de bronces, "pieza de taller tartésico, fabricada para un régulo celta hispano y con ello reivindicar como del mismo foco metalúrgico la totalidad de las piezas hispanas estudiadas por Blanco Freijeiro. Que sea la propia Gadir o una Tartessos no localizada, no se puede aún precisar (...) Lo más razonable es buscar el taller entre Carmona, Sevilla y Huelva. ¿Será Tartessos la propia Sevilla (...)? (...) El taller que Blanco Freijeiro y García Bellido buscan hacia Gadir, es para nosotros simplemente Tartessos" (Maluquer 1957: 166, 168 n. 26). Ciertamente, como indica Álvarez Martí-Aguilar (2005: 229), Maluquer defiende un Tartessos indígena, no fenicio o púnico, pero su Tartessos es celta, con régulos celtas como Argantonio.

Tres años después lo dejaba claro al volver a reflexionar sobre este objeto (Maluquer 1960: 284). El "bronce Carriazo. Consideramos tal pieza con sus prótomos de patos y su diosa hatórida como una verdadera simbiosis entre el mundo indoeuropeo y el mundo orientalizante, y nos parecía que ese aspecto era precisamente el más apropiado para ser atribuido a Tartessos, en la onomástica de algunos de cuyos reyes históricos como Argantonio se ha querido rastrear también la presencia de un elemento indoeuropeo".

Ya conociendo el descubrimiento del Tesoro de El Carambolo, ocurrido el 30 de septiembre de 1958, Maluquer (1958c: 201-202) señalaba la diferencia entre su propia escuela salmantina y la madrileña de García y Bellido y Blanco Freijeiro. La "escuela arqueológica madrileña (...) se orientaba hacia el reconocimiento de la existencia de una etapa artística orientalizante, paralela al periodo orientalizante de Grecia y Etruria”. En cambio, la suya, por la presencia de "elementos de la Meseta, con resabios de orientalismo, nos llevaron a valorar con todo rigor las posibles causas de esa expansión céltica hacia el sur. Nos embarcamos en el problema minero del cobre y del estaño y una y otra vez nuestros trabajos apuntaban hacia Tartessos (...) y en consecuencia calificamos inmediatamente de tartésicas todas las manifestaciones de ese elemento". Sus celtas tartesios además son indoeuropeos como el propio Maluquer (1958c: 203) se encarga de resaltar, "De la intensidad de tal preocupación dará una idea el que en los últimos ocho años en la Universidad de Salamanca se hayan dictado dos cursos de doctorado, dedicados a 'Tartessos y sus problemas', y otros tres sobre la 'Expansión indoeuropea en la Península"”.

En todo caso, la estrecha relación de amistad entre ambos continuaba. Carriazo comenzó la excavación de El Carambolo la tarde del 2 de octubre de 1958, que se desarrolló de manera sistemática entre el 3 y el 22 de octubre, con la participación también de Collantes de Terán, Fernández-Chicarro, secretaria del Museo Arqueológico de Sevilla, y el fotógrafo Antonio González-Nandín. Carriazo (1973: 197) invitó a Maluquer a participar en la excavación desde el principio, carta que recibió el día 4, no incorporándose hasta la tarde del jueves 15 de octubre, colaborando hasta el mediodía del sábado 17, regresando esa tarde por avión a Madrid. La tarde del mismo día 15, en que marcharon Carriazo y Collantes de Terán a una reunión de la Comisión Provincial de Monumentos de Sevilla y después a una boda, se dedicó a dibujar los perfiles de la excavación, mientras los obreros seguían excavando (Maluquer 1958d/1994: 1-2; Carriazo Arroquia 1973: 505).

Como señala Carriazo (1973: 228, 234), a Maluquer "Le faltó la observación de las primeras fases exploratorias, y sobre todo la del momento final, cuando procedimos a demoler aquel muro-testigo que habíamos reservado casi en el eje del fondo de cabaña, recogiendo meticulosamente sus materiales, y apuramos todo el estrato inferior del yacimiento, hasta la tierra virgen". Concretamente, "el estrato IV, que es el piso de cenizas, por debajo del nivel F' de Maluquer (y que éste no llegó a ver), presenta una potencia de hasta 70 $\mathrm{cm}$, bajo el extremo oriental del fondo de cabaña, y va disminuyendo hasta $30 \mathrm{~cm}$, y aún menos, a medida que se va hundiendo el piso de habitación".

La lectura de la estratigrafía con los años acabó provocando una extraña paradoja. Partiendo del buen registro documental de Maluquer y su reconocida capacidad interpretativa y como arqueólogo, se priorizó la documentación obtenida por él en sólo dos días de trabajo que el registro obtenido por Carriazo, el director de la excavación, que además continuó 5 días más excavando en profundidad, entre el 18 y el 22 de octubre. Así, Aubet (1992-93: 329, 339) indica que "la lectura que hace Maluquer de los datos arqueológicos resulta correcta y coherente, en tanto que la interpretación de la estratigrafía del fondo de cabaña publicada 
por Carriazo resulta incomprensible”. Según esta autora, "Carriazo engloba dentro de un mismo conjunto los estratos E y F de Maluquer y mezcla las cerámicas (Carriazo 1973: 233 y 505), pese a pertenecer a horizontes inequívocamente distintos. Esta confusión explica que este autor mencione la presencia de cerámicas a torno en el fondo de cabaña, cuando la estratigrafía de Maluquer muestra de forma muy clara las diferencias morfológicas que existen entre el estrato F (final de la ocupación de la cabaña) y el E (o estrato de abandono y transición al mundo de las importaciones fenicias...)". La razón era que Carriazo (1973: 505) cita la presencia en su estrato III también de cerámica pintada tipo Carambolo, pero "más raramente". En cambio, otros autores como Escacena (2004: 35 y 2010: 114-116), han resaltado la presencia de cerámica a torno ya desde el estrato IV.

El estrato III de Carriazo (1973: 233), que engloba los niveles E y F de Maluquer, "se identifica con el piso de la cabaña y los materiales calcinados que cayeron sobre él, resulta, naturalmente, el más rico y de mayor interés arqueológico". Mientras que el estrato IV, no visto por Maluquer, presentaba "la mejor cerámica pintada de tipo tartésico (clase 18), y la mayor parte de la de retícula bruñida (clase 17) y de los platos menudos y finísimos, orientalizantes (clase 7)" (Carriazo Arroquia 1973: 234). Estos últimos eran descritos como "Pocos fragmentos de unos vasos menudos, a torno, de barro gris o negruzco, de paredes tenues y formas muy elegantes, de aire griego u oriental", aunque posteriormente los clasifica también como indígenas, "Algunos fragmentos presentan grupos de bullones en la base. Otros, filetes pintados de rojo, paralelos e inmediatos al borde" (Carriazo Arroquia 1973: 482, 493, 538-539 fig. 387-389). No obstante, una de las cerámicas presenta decoración de líneas con bruñido exterior en su fondo (Carriazo Arroquia 1973: 540 fig. 390).

Desde el momento de la excavación, Maluquer caracterizó el sector excavado como parte de una vivienda, "Del estudio de la estratigrafía puede deducirse que la zona excavada comprende, por una parte, el interior de una vivienda o choza que pereció en un gran incendio, o en varios; y por otra, una zona de vertedero exterior que probablemente estuvo al descubierto durante la existencia de aquella casa" (Maluquer 1959: 48). Así lo había recogido en su diario de campo, mencionando que el "estrato E nos parece haber sido formado por una etapa de abandono sobre los restos de una vivienda incendiada" (Maluquer 1958d/1994: 14).

La zona excavada en el Carambolo Alto resultaba extraña como acababa reconociendo el propio Carriazo
(1973: 233), "la calificación de fondo de cabaña no está exenta de alguna vacilación. Principalmente por su riqueza cerámica, desproporcionada a la pobreza de los materiales y del sistema constructivo; y no se diga a la del mismo tesoro, si, como creemos, está en relación con el yacimiento. La verdad es que no estamos acostumbrados a ver fondos de cabaña con un ajuar tan copioso, ni tan evolucionado. Nuestros fondos de cabaña son neo-eneolíticos, circulares y de ajuar mucho más simple; lo mismo que los silos (...) El ajuar del Carambolo parece que está pidiendo una vivienda de mayor solidez y monumentalidad".

Carriazo reservó el primer artículo del tesoro de El Carambolo para la revista Zephyrus que dirigía Maluquer (1958c: 203), pero éste indica que "Causas imprevistas y ajenas a nuestra voluntad lo impiden”. Como señaló Carriazo (1973: 18) años después, fueron los elevados costes de las fotografías lo que lo impidió, "Un primer informe de conjunto estuvo listo para la imprenta inmediatamente, y no se publicó por la carestía de las ilustraciones" en el Zephyrus de enero de 1959 (Carriazo 1969/1978: 121, 136-137), saliendo al final en The Illustrated London News del 31 de enero de 1959.

Las repercusión del tesoro del Carambolo ejemplifica que en el Primer Symposium de Prehistoria de la Península Ibérica, el cual los catedráticos más jóvenes, liderados por Maluquer, organizaron en Pamplona en 1959 sin la tutela de los catedráticos más antiguos, Pericot, Mergelina, García y Bellido y Almagro Basch, el tema elegido por Maluquer fue Tartessos, concretamente "Nuevas orientaciones en el problema de Tartessos".

En este trabajo señala la influencia céltica en las joyas del tesoro. "El matiz celtizante se advierte por ejemplo en las famosas joyas halladas en el tesoro del Carambolo de Sevilla, en particular en la estructura pesada y maciza de los dos grandes brazaletes (...) y más aún en los grandes colgantes en forma de reloj de arena", pero en el Mediterráneo frente a Fenicia sugiere un nuevo foco de influencias y señala que quizás tengan "forma de lingote de cobre chipriota" (Maluquer 1960: 284). La causa era la búsqueda de paralelos para la cerámica pintada de El Carambolo, la cual le hace dirigirse hacia Chipre como foco de procedencia de las influencias orientalizantes en Tartessos. "Hemos visto cómo los temas de la cerámica pintada del Carambolo son de neta inspiración chipriota, incluso de franca imitación" por lo que considera que "los tartesios son esencialmente gente relacionada con Chipre, es decir, que la colonización tartésica es en realidad una colonización chipriota" (Maluquer 1960: 287). 
A su juicio, "la civilización tartésica es en esencia una cristalización en Occidente de un estímulo chipriota probablemente ejercido desde muy antiguo en el segundo milenio a consecuencia de la búsqueda de la riqueza minera $(. .$.$) este elemento cultural antiguo y$ también quizás étnico chipriota se vitaliza al estímulo de los contactos con las poblaciones indoeuropeas del Bronce final que alcanzan en época temprana el sudoeste peninsular". En cambio, la colonización fenicia tiene un peso menor. "Este estímulo fue constantemente renovado a fines del segundo milenio y comienzos del primero al amparo probablemente de las navegaciones históricas fenicias" (Maluquer 1960: 297), pero cuando ya estaba formado el Tartessos celta indoeuropeo.

Estos "elementos chipriotas, no fenicio continentales, son los introductores de la escritura tartésica en Occidente. Esta escritura se halla perfectamente fijada en el siglo VI si no antes, y se utiliza en una amplia zona del mediodía peninsular que abarca además del Algarbe y Alemtejo, la cuenca baja del Guadiana, y probablemente la totalidad de la cuenca del Guadalquivir" (Maluquer 1960: 296).

En esta escritura, "parece rastrearse en la onomástica de las mismas, un elemento celta peninsular o indoeuropeo que adquiere cada vez mayor interés si tenemos en cuenta que con las fuentes históricas en la mano puede afirmarse rotundamente que el proceso de celtización del extremo sudoeste de la península (zona precisamente donde aparecen estas estelas) se hallaba completamente establecido en época tan antigua como el siglo VI a.C." (Maluquer 1960: 296).

\section{TARTESSOS Y EL TESORO DEL CARAMBOLO}

El interés de Carriazo por Tartessos, aparte por sus orígenes andaluces, nació desde la lectura de la traducción castellana del Tartessos de Schulten (1922a), aparecida en 1924, que le impulsó a comenzar a redactar en esos años "un libro sobre Tartessos (..) complemento, más que una réplica de Schulten", donde pensaba analizar los "textos publicados por eruditos e historiadores españoles de los siglos XVI, XVII y XVIII, ignorados o silenciados por Schulten, para hacerse descubridor de Tartessos", tema en el que estuvo trabajando en la Biblioteca del Ateneo de Madrid, a la vez que preparaba las oposiciones de cátedra (Carriazo Arroquia 1960/1978: 64 y 1973: 15-16).

El 30 de septiembre de 1958 se produjo el hallazgo casual de un tesoro de oro en El Carambolo (Sevi1la), con la inmediata realización de excavaciones por
Carriazo en el yacimiento dos días después por su condición de Delegado de Zona del Servicio Nacional de Excavaciones (Carriazo Arroquia 1958, 1959, 1970a y 1973), convirtiéndose en el factor desencadenante de un nuevo impulso al ansiado proyecto de localizar el emplazamiento de Tartessos. Las actuaciones fueron posibles gracias a la concesión de una Ayuda de Investigación de 500.000 pesetas por parte de la Fundación Juan March, que ayudó a gestionársela Gómez-Moreno, quien visitó el yacimiento e inspeccionó el tesoro en marzo de 1959 (Carriazo Arroquia 1977: 39).

La rapidez de reacción fue clave para no perder la oportunidad científica de contextualizar el tesoro. Como el propio Carriazo indicaba en una carta a Gómez-Moreno en mayo de 1959, "Las joyas aparecieron por casualidad, pero la idea de empezar inmediatamente y de conducir las excavaciones y el estudio, se la disputo al más pintado" (Carriazo Rubio 2001: 33).

El punto de vista de partida desde el primer artículo de prensa en $A B C$ sobre el descubrimiento es evidente, "Es imposible, por mucha que quiera ser nuestra precaución y reserva, dejar de relacionar esta cultura con el pueblo de Tartessos, la más antigua entidad política superior de todo el Occidente europeo" (Carriazo Arroquia 1958: 37), que reafirmó en su discurso de ingreso en 1958 en la Real Academia de Bellas Artes de Santa Isabel de Hungría en Sevilla (Carriazo Arroquia 1960/1978: 58), calificando a "Tartesos (...) la primera entidad política superior de todo el Occidente europeo".

La monografía de la excavación, cuya finalización anunciaba en 1963 (Carriazo Arroquia 1964/1978: 23), fue entregada por Carriazo a la Dirección General de Bellas Artes en mayo de 1965, durante el mandato de Nieto Gallo, pero por su alto presupuesto se le devolvió en febrero de 1966, hasta que consiguió firmar un contrato editorial en mayo de 1967, para su publicación en 1969, el cual nunca se materializó. Finalmente, fue retomada de nuevo por el nuevo Director General de Bellas Artes, Pérez Embid, sevillano de adopción por haber sido profesor de su universidad (Carriazo Arroquia 1969: 334 y 1969/1978: 137), que consiguió publicar a gran lujo el libro Tartessos y El Carambolo de Carriazo (1973), pero lamentablemente con 8 años de retraso y 15 años después de la primera excavación en El Carambolo.

Esta fue una de las pocas grandes satisfacciones de Carriazo tras su jubilación a los 70 años el 16 de mayo de 1969 (AGA, 21/20.417), aunque se ha sugerido el año 1971 (Pasamar y Peiró 2002: 169), pues sufrió pronto la pérdida de su mujer el 25 de diciembre de 1969. No obstante, después tuvo el reconocimiento de 
ser nombrado Académico de Número de la Real Academia de la Historia en mayo de 1977, con 78 años (Carriazo Arroquia 1977), a la que pertenecía como Correspondiente desde el 16 de noviembre de 1945, Hijo Adoptivo de Sevilla en 1986 con 87 años e Hijo Predilecto de Andalucía en 1987, hasta fallecer el 20 de junio de 1989 con 90 años.

No aporta Carriazo hasta el final de su monografía de 1973 unas conclusiones elaboradas sobre Tartessos, sino se queda en la descripción de nuevos materiales y yacimientos, pero sí admite dudas sobre una identificación automática del registro cerámico con Tartessos. Lo reconoce el propio autor, "no incluimos en este libro ni el estudio de las fuentes literarias sobre Tartessos, ni la historia de la cuestión tartésica. Ello nos distraería del objeto principal, que es dar a conocer los nuevos materiales arqueológicos, que suponemos tartesios. Aunque no lo fueran, estos materiales son tan nuevos y tan valiosos que merecen toda nuestra atención". En consecuencia, "Nuestro tema es el contenido arqueológico de la cultura de Tartesos, revelado por los yacimientos que hemos excavado sistemáticamente, $\mathrm{y}$ el estudio de sus ajuares (...) Así nos curamos en salud de cualquier exceso de subjetivismo" (Carriazo Arroquia 1973: 15, 58).

Sus puntos principales son claros. Autoctonismo indigenista. "Es imposible imaginar que todo ese volumen de elementos sea fruto de una importación, o de una colonización (...) todos los materiales que vamos conociendo de la cultura de Tartesos se han creado en el propio suelo" (Carriazo Arroquia 1973: 667-668).

No obstante no descarta aportes externos, "la civilización de Tartessos, diríamos que fue una evolución in situ de las grandes creaciones del neoeneolítico del Bajo Guadalquivir (...) y por la confluencia (...) de dos corrientes de influencias, la una aportada por los marinos del Mediterráneo oriental y la otra por inmigrantes de la Europa central" (Carriazo Arroquia 1973: 12), esto es, "la llegada de los celtas, que ocurre en pleno período tartésico, y en parte contribuye a su apogeo" (Carriazo Arroquia 1973: 56).

No obstante, en su propuesta hay un escaso protagonismo de los celtas tartésicos de Maluquer, cuya llegada considera básicamente posterior al declive de Tartessos, "la presencia de los celtas en la Baja Andalucía y la difusión del hierro en el valle inferior del Guadalquivir constituyen un término ante quem del florecimiento de Tartesos (...) la ruina de Tartessos ocurre cuando, con la introducción del hierro, el bronce deja de ser el metal precioso e indispensable que había sido durante más de tres siglos. Esta ruina económica explica el ocaso de la entidad política de Tartessos" (Carriazo Arroquia 1973: 46)

Ya el propio Gómez-Moreno desautorizaba en la prensa, en declaraciones al diario $Y a$ el 15 de octubre de 1958 (Fernández Gómez 2001: 35), cualquier relación de los tartesios con los celtas, "no creo que un pueblo bárbaro como el celta llegase a dominar en tierras tartésias, que, además eran de aluvión y, por lo tanto, impropias para el pastoreo".

Por tanto, se trataba de una economía basada en la minería y la metalurgia, "La Península Ibérica, y especialmente Tartesos, pusieron en circulación en el Mediterráneo la mayor masa de oro, plata y estaño que el mundo ha conocido antes de la Edad Moderna" (Carriazo Arroquia 1973: 668).

Otra premisa es el origen de Tartessos desde el Calcolítico y su continuidad hasta el Bronce Final, "el estado de cosas del pleno Eneolítico se ha conservado en el bajo Guadalquivir hasta fechas más recientes que en el resto de Andalucía, y que ha resistido la invasión masiva de lo argárico, hasta darse la mano con la Segunda Edad del Bronce" (Carriazo Arroquia 1973: 671). Eso se refleja también en el registro cerámico, "así es la cultura material de Tartesos. Fuertemente enraizada (...) en la tradición eneolítica" (Carriazo Arroquia 1973: 673).

Este indigenismo también lo reflejaría el Tesoro de El Carambolo. "Para nosotros no cabe duda de que el arte de las joyas del Carambolo es un arte indígena, con sus antecedentes inmediatos en la orfebrería española de la Edad del Bronce. Cualquier duda de última hora ha venido a resolverla el tesoro de Villena. Su filiación [in]mediata viene de nuestro riquísimo Eneolítico. La aportación oriental es un accidente de procedimientos técnicos (granulado) o de sugestiones temáticas (el anillo signatario reducido a colgante de adorno). El material, el espíritu y la mano de obra son indígenas" (Carriazo Arroquia 1973: 186-187).

Desde el Calcolítico se evidencia una jerarquización social que alcanzó su máxima expresión con Tartessos, "Esta monumentalidad y esta riqueza del dolmenismo en la zona tartésica postulan un desarrollo económico, social y cultural ciertamente extraordinario. Para construir esos magníficos monumentos han tenido que darse, como circunstancias indispensables, una riqueza general y una jerarquización de la sociedad (...) Esto es un paso decisivo para llegar a esa monarquía (con todos los distingos y salvedades que se quieran) que gobernó en Tartesos" (Carriazo Arroquia 1973: 670), la cual considera una "monarquía patriarcal (...) y el rey Argantonio es el protagonista" (Carriazo Arroquia 1973: 674). 


\section{SU INTERPRETACIÓN SOBRE LA PREHISTORIA RECIENTE DE LA PENÍNSULA IBÉRICA}

Los primeros trabajos de campo de Carriazo van a realizarse cerca de la población natal de su familia en Quesada (Jaén), con el descubrimiento de enterramientos argáricos en Corral de Quiñones en 1924. Una segunda etapa, vinculada a la prehistoria y protohistoria, comienza con su nombramiento como Delegado de Zona del Servicio Nacional de Excavaciones del Distrito Universitario de Sevilla en 1956, donde destaca la excavación de diversos megalitos y el descubrimiento del tesoro del Carambolo en 1958.

Referente al Calcolítico, siguiendo las tesis de Gómez-Moreno, defiende Carriazo (1931a: 110) la denominación de tartésico, pues a su juicio "todos los trabajos posteriores confirman, directa o indirectamente, el acierto de la ecuación Tartessos=Eneolítico", asociación que cree ver ratificada en el importante desarrollo de los enterramientos megalíticos y del vaso campaniforme. "No ya sólo la arquitectura dolménica, la cerámica del vaso campaniforme (...) descubre su origen y centro de gravedad en el valle inferior del Guadalquivir, en la Tartéside".

En este sentido, considera que el "gran avance" en los estudios prehistóricos sobre el Calcolítico "ha sido la localización en Andalucía de la evolución y desarrollo original de las tumbas megalíticas, así las de forma rudimentaria como las más perfectas del grupo de Antequera y la atribución de estas creaciones a los tartesios, dueños del primitivo comercio de los metales, mediante el cual realizan los dólmenes españoles su expansión europea" (Carriazo Arroquia 1924: 172-173).

En relación al Sureste, su excavación en Corral de Quiñones (Quesada, Jaén) supuso la extensión de los límites del Argar hacia Jaén, al situarse en el Pasillo de Pozo Alcón-Guadiana Menor, subsidiario del Guadalquivir.

Para el Bronce argárico, Corral de Quiñones suponía "un jalón muy seguro para el esclarecimiento de (...) la difusión de la cultura de El Argar", señalando "que el camino Vera-Baza-Quesada conduce a la famosa zona minera que en lo antiguo se llamó de Cástulo y ahora de Linares" (Carriazo Arroquia 1925: 174, 184, 186-187, 190). Los criterios que utiliza para definir el yacimiento como argárico fueron el emplazamiento, los enterramientos en fosas en el interior de la vivienda y diversos paralelos artefactuales.

En una posterior aportación sobre el tema, considera al Argar una "clara evolución local del Eneolítico", que "nace por tierras de Almería, de donde irradia con diversa intensidad a las regiones vecinas". Uno de sus límites estaría "en la región de Linares" donde "termina por el Oeste la expansión directa de la cultura argárica".

El factor que en su época había cohesionado internamente a la cultura argárica había sido el "miedo de un enemigo atrevido y fuerte, seguramente codicioso de sus riquezas. Miedo que le obliga a encastillarse en las pequeñas acrópolis, defendidas por murallas. Miedo que les induce a enterrar a sus difuntos en el interior de sus propias viviendas. Miedo que prodiga las armas, de las que no dejan de proveerse ni las mujeres ni los muertos. Miedo que espolea el trabajo y la acumulación de productos" (Carriazo Arroquia 1947: 756, 781, 836).

Estos criterios autoctonistas parece revisarlos parcialmente puesto que el Bronce argárico lo considera "una evolución in-situ del anterior Eneolítico, matizada por influencias exteriores del Mediterráneo oriental". Igualmente, en relación a los límites, considera que "se expande por casi toda la península ibérica sin evolucionar", pero "apenas salta por el Pirineo y se difunde por Europa realiza una rápida, intensa y brillante evolución” (Carriazo Arroquia 1980: 164, 166).

También las opiniones y el trabajo arqueológico de Carriazo influyeron sobre otros colegas, no sólo con los materiales de El Carambolo. Ejemplo de ello fue su revalorización de los thymateria de Lébrija, que en su discurso de apertura al VIII Congreso Nacional de Arqueología señalaba que "con sus siete kilos y medio corridos de oro (...) Si alguna pieza arqueológica merecía presidir este Congreso y su Exposición aneja es este lote formidable, ante el que Schulten y los tartesistas han pasado con los ojos cerrados" (Carriazo Arroquia, 1964/1978: 24), publicándolos Almagro Basch (1964) al año siguiente. Ya había destacado Carriazo (1947: 845), años antes, la importancia de estas "piezas votivas para adorno de un altar" que "Son inconcebibles sin una organización pujante, asentada en la explotación y comercio de los metales (...) precisamente por las inmediaciones de Lebrija se están buscando las ruinas de Tartessos", en referencia a las excavaciones en Mesas de Asta. También influyó su reexcavación del dolmen de La Pastora en 1961, donde descubrió 14 m. más del corredor, "Y es curioso que mientras nosotros excavábamos esta prolongación, Martín Almagro [1962] ha publicado el ajuar de su excavación anterior, que se había conservado inédito en el Museo Arqueológico Nacional" (Carriazo Arroquia 1964/1978: 21), puntas de javalina cuya importancia Almagro Basch (1959) ya había resaltado pocos años antes. 


\section{CONCLUSIONES}

Juan de Mata Carriazo se licenció con 21 años en la Universidad Central de Madrid, leyó allí su tesis doctoral con 24 años y ganó en 1927 la Cátedra de Historia Antigua y Media de España de la Universidad de Sevilla con 28 años, contando con un curriculum de 1 libro y 10 artículos.

Miembro del Centro de Estudios Históricos desde 1922, donde fue discípulo de Manuel Gómez-Moreno, impartió clases de Historia, Arte y Geografía en el Instituto-Escuela de Madrid hasta que sacó las oposiciones en 1927, docencia que le formó para aplicar los principios didácticos de la Institución Libre de Enseñanza.

En la investigación de Carriazo hay un trabajo regular hasta la pérdida de la oposición de la Cátedra de Arqueología de la Universidad Central de Madrid en 1931, frente a García y Bellido que tenía los apoyos de Mélida y Obermaier, aunque los méritos de Carriazo eran entonces claramente superiores en investigación, docencia y excavaciones arqueológicas. Este hecho debió desmoralizarle, a lo que pronto se le sumó su casi inmediato nombramiento como Director del InstitutoEscuela de Sevilla y el simultáneo nacimiento de su segundo hijo, ambos en febrero de 1932, y un año después, asumir las excavaciones de Itálica entre 1933-35. En esta etapa entre 1932-36, sus artículos científicos prácticamente desaparecen (Carriazo Arroquia 1932a, 1935a y 1935b).

Durante la Guerra Civil, Carriazo se encontraba con su familia en Madrid en el momento de la sublevación del 18 de julio de 1936, siendo inicialmente adscrito a la Universidad Central de Madrid y posteriormente destinado a la Universidad de Valencia entre finales de 1936 y de 1938, actuando a partir de 1937 como Secretario de la Subsección de Excavaciones del Consejo Central de Archivos, Bibliotecas y Tesoro Artístico, que le obligó a realizar algunas excavaciones de urgencia y la catalogación de fondos documentales. A partir de enero de 1939 realizó esta función en la provincia de Jaén. En estos años trabajó en la preparación de los tres primeros volúmenes de la Colección de Crónicas Españolas que le había encargado Ortega y Gasset para la editorial Espasa-Calpe.

Con un proceso abierto en la zona nacional desde 1937, poco después de reincorporarse a la Universidad de Sevilla a fines de abril de 1939, fue detenido el 3 de mayo de 1939 y conducido a prisión donde permaneció durante 9 meses y medio hasta el 14 de febrero de 1940, abriéndosele un Consejo de Guerra con Procedimiento Sumarísimo de Carácter Urgente, acusado de "delito de auxilio a la rebelión". La razón de fondo de su acusación fue haber sido director del Instituto-Escuela de Sevilla por su vinculación con la Institución Libre de Enseñanza, a lo que se sumó ocupar un cargo en el Consejo Central de Archivos, Bibliotecas y Tesoro Artístico, su pertenencia a Izquierda Republicana por su relación con el Rector de la Universidad de Sevilla durante la República, el doctor y catedrático Estanislao del Campo, e incluso haber accedido a la dirección de las excavaciones de Itálica favorecido por miembros de la Institución Libre de Enseñanza, cargos de los que finalmente fue absuelto y poco después resultó depurado favorablemente por el Ministerio de Educación Nacional el 21 de mayo de 1940.

Muy afectado por los 9 meses y medio que permaneció en prisión y con la actitud de algunos de sus compañeros de la universidad sevillana, cuyo Rector, José Mariano Mota, lo había calificado inicialmente de "simpatizante con las izquierdas", aunque después lo apoyó en su expediente de depuración, intentó trasladar su cátedra de Sevilla a Madrid en septiembre de 1940, al quedar vacante, por exilio de Sánchez-Albornoz, la Cátedra de Historia Antigua y Media de España, pero pese a sus mayores méritos se eligió al catedrático falangista Carmelo Viñas y Mey, que detentaba esta plaza en Santiago de Compostela.

Fracasado el traslado de su cátedra a la Universidad de Madrid y vetado por Martínez Santa-Olalla para que desempeñase el cargo de Comisario Provincial de Excavaciones Arqueológicas en Sevilla por su ideología de centro-izquierda y ser discípulo de Gómez-Moreno, focalizó su trabajo en la publicación de los 9 volúmenes la Colección de Crónicas Españolas entre 194046 y posteriormente en su estudio de la Historia de la guerra de Granada hasta 1958. Por ello, su obra presenta un vacío bibliográfico completo en temas de arqueología de 21 años, entre un informe de las excavaciones en Itálica de antes de la Guerra Civil (Carriazo Arroquia 1935b) y la primera reseña del hallazgo del tesoro del Carambolo (Carriazo Arroquia, 1958), salvo un extenso capítulo sobre la Edad del Bronce en la Historia de España de Menéndez Pidal (Carriazo Arroquia 1947), pues en 1924 ya había excavado el yacimiento argárico del Corral de Quiñones (Quesada, Jaén), que había supuesto la demostración de la expansión de la cultura argárica hasta dicha provincia.

Cesado Martínez Santa-Olalla como Comisario General de Excavaciones Arqueológicas en 1955, pudo volver a ocuparse la arqueología a partir de que pasó a desempeñar desde 1956 el cargo de Delegado de Zona del Servicio Nacional de Excavaciones del Distrito 
Universitario de Sevilla, y pronto se vio premiado por el espectacular descubrimiento de El Carambolo en 1958, estimulándole para investigar Tartessos, pero ya entonces tenía 59 años y su principal monografía, redactada en 1965, se publicó, después de un prolongado retraso de 8 años por los elevados costes de publicación y 15 años después de la excavación, cuando ya tenía 74 años en 1973.

La continuidad de las excavaciones de Itálica quedaron frustradas en 1957 cuando Carriazo trató de retomarlas, al exigir García y Bellido en la Junta Consultiva de Excavaciones participar él como codirector de las mismas junto a Carriazo y Collantes de Terán. Nieto Gallo al llegar a la Dirección General de Bellas Artes en 1961, que le podía haber beneficiado al ser un discípulo de Mergelina, mantuvo la política de la Junta Consultiva de Excavaciones de continuar transfiriendo el dinero de Itálica a las excavaciones en Madinat al $\mathrm{Za}$ hrâ' en Córdoba.

En general, Carriazo muestra una cierta incapacidad de atraer y formar alumnos en arqueología, a pesar de todos los años de docencia en Sevilla entre 1927-69, pues sólo cabe mencionar la tesis de Francisco Collantes de Terán (1956 y 1977), Sevilla en la Antigüedad y Edad Media, Estudio Topográfico y Arqueológico, Comisario Provincial de Excavaciones Arqueológicas en Sevilla y compañero en muchos de los trabajos de campo de Carriazo, que además tenía su misma edad. Al principio, entre 1927-36, debió influir su juventud, pues entonces tenía entre 28 y 37 años y no poder consolidar sus excavaciones en Itálica entre 1933-35, al quedar paralizadas en 1936. Pero teniendo en cuenta su larga experiencia previa con alumnos en el InstitutoEscuela de Madrid y Sevilla, después de la Guerra Civil sólo cabe buscar la explicación en su retraimiento personal tras su desagradable experiencia en la cárcel entre 1939-40. Cuando volvió a dedicarse a la arqueología de campo ya tenía 57 años en 1956 y 59 años cuando se produjo el descubrimiento de El Carambolo.

En relación a artículos sobre prehistoria o protohistoria, se observa que de los alumnos de GómezMoreno, Carriazo, a pesar de su menor dedicación a la arqueología, es claramente el mejor si lo comparamos con Mergelina, Camps, Navascués o Nieto Ga1lo. De sus posibilidades como investigador ya antes de ser catedrático, para la prehistoria es destacable su artículo La cultura de El Argar en el Alto Guadalquivir. Estación de Quesada (Carriazo Arroquia 1925a) y para época romana El sarcófago cristiano de Berja (Carriazo Arroquia, 1925d), aunque la mejor plasmación de su solidez aparece en un trabajo sobre fuentes documentales, Mosén Diego de Valera: Crónica de los Reyes Católicos (Carriazo Arroquia 1927c). Superado el bache de 1932-35 y el parón de la Guerra Civil entre 1936-39, desde 1940, con Carriazo ya con 41 años, nos encontramos con un investigador consolidado que plasma inmediatamente el trabajo acumulado durante los años anteriores en los 9 volúmenes la Colección de Crónicas Españolas entre 1940-46 sobre las crónicas castellanas del siglo XV, durante los reinados de Juan II, Enrique IV y los Reyes Católicos. Por entonces ya estaba escasamente interesado en publicar artículos, y planificaba su investigación para elaborar monografías. Esa concepción se plasma en su notable síntesis de la Edad del Bronce (Carriazo Arroquia 1947a), su único trabajo arqueológico en un periodo de 21 años, donde sugiere lo que pudo ser y se frustró. Recuperado para la arqueología desde 1958, después de haber estado varios años dedicado a la Historia de la guerra de Granada, su trabajo orientado a la elaboración de libros se proyecta en las primeras monografías sobre El Carambolo y Ébora (Carriazo Arroquia 1970a, 1970b), que anuncian su principal obra, Tartessos y El Carambolo (Carriazo Arroquia 1973) donde defendió una génesis autóctona de Tartessos, cuyos orígenes remonta al Calcolítico. Pero este libro, saturado de extensos textos entrecomillados tomados de otros autores cuya opinión prefiere ante la inseguridad en el criterio propio, pone en evidencia que el tiempo no pasa en vano y muestra sus carencias en la interpretación de los datos arqueológicos, que no había podido actualizar adecuadamente con el paso de los años, por lo que optó correctamente por centrarse en presentar el novedoso registro cerámico de El Carambolo, apoyado por un excelente aparato gráfico en color.

La carrera científica de Carriazo tuvo grandes fracturas, como la pérdida de la Cátedra de Arqueología de la Universidad Central de Madrid en 1931 ante García y Bellido. Su prisión y consejo de guerra entre 1939-40 que afectó a su carácter y lo convirtió en una persona reservada. La pérdida del concurso de traslado a la Cátedra de Historia Antigua y Media de España de la Universidad Central de Madrid en 1940 ante Viñas Mey. El veto de Martínez Santa-Olalla a que fuera Comisario Provincial o incluso Comisario Local, optando por Collantes de Terán entre 1941-55, quien desde 1937 se había hecho cargo de las excavaciones de su antiguo yacimiento de Itálica. El veto de García y Bellido a poder retomar las excavaciones en Itálica si no figuraba él como codirector en 1957. O los 8 años en el retraso editorial de la publicación de El Carambolo hasta 1973. Algunos de estos aspectos afectaron gravemente 
a su trayectoria personal y científica, pero también tuvo grandes satisfacciones como la cátedra de Sevilla en 1927, la dirección de las excavaciones de Itálica entre 1933-35, la publicación de los 9 volúmenes la Colección de Crónicas Españolas entre 1940-46 o la excavación de El Carambolo entre 1958-61.

\section{AGRADECIMIENTOS}

El trabajo se adscribe al Grupo de Investigación Hum F-003 de la Universidad Autónoma de Madrid, dirigido por J. Blánquez. Queremos agradecer la gentileza de Juan Luis Carriazo Rubio, a Salvador Quero la posibilidad de poder consultar la documentación del Archivo Martínez Santa-Olalla (ASO) en el Museo de los Orígenes de Madrid y a Daniel Gozalbo por sus atenciones en el Archivo General de la Administración (AGA).

\section{BIBLIOGRAFÍA}

ABAD CASAL, L. (2008): "El rescate científico de la antigüedad romana en Andalucía: la arqueología como disciplina en el siglo XX (hasta 1985)", en F. Amores, J. Beltrán y J. Fernández Lacomba (eds.), El rescate de la antigüedad clásica en Andalucía: 69-80. Fundación Focus-Abengoa, Sevilla.

ALGORA ALBA, C. (1996): El Instituto-Escuela de Sevilla (1932-1936). Una proyección de la Institución Libre de Enseñanza. Diputación de Sevilla, Sevilla.

ALMAGRO BASCH, M. (1959): "Elementos para la cronología absoluta del Bronce I en la Península Ibérica", I Congresso Nacional de Arqueología (Lisboa, 1958): 161-185. Lisboa.

- (1962): El ajuar del 'Dolmen de la Pastora'de Valencina del Alcor (Sevilla). Sus paralelos y su cronología. Trabajos de Prehistoria 5. Madrid.

- (1964): Los thymateria llamados candelabros de Lébrija (Sevilla). Trabajos de Prehistoria 13. Madrid.

ÁLVAREZ MARTÍ-AGUILAR, M. (2005): "El orientalizante peninsular como problema historiográfico", en S. Celestino y J. Jiménez Ávila (eds.), El periodo orientalizante. III Simposio Internacional de Arqueología de Mérida (Mérida, 2003). Anejos de Archivo Español de Arqueología 33: 227-235. Instituto de Arqueología de Mérida, Consejo Superior de Investigaciones Científicas. Madrid.
- (2010): "Carriazo y su interpretación de los hallazgos de El Carambolo en el contexto de los estudios sobre Tartesos", en M $\mathrm{M}^{\mathrm{a}}$.L. de la Bandera y E. Ferrer (eds.), El Carambolo. 50 años de un tesoro (Sevi1la, 2008): 53-97. Universidad de Sevilla, Sevilla.

AUBET SEMMLER, M‥E. (1992-93): "Maluquer y El Carambolo", Homenaje a Manuel Pellicer Catalán. Tabona 8 (2): 329-350.

BELTRÁN, R. (2001): "Don Juan de Mata Carriazo, editor de crónicas medievales", en J.L. Carriazo Rubio (ed.), Juan de Mata Carriazo y Arroquia. Perfiles de un centenario (1899-1999): 59-109. Universidad de Sevilla, Sevilla.

BENDALA GALÁN, M. (2001): "Don Juan de Mata Carriazo, arqueólogo", en J.L. Carriazo Rubio (ed.): Juan de Mata Carriazo y Arroquia. Perfiles de un centenario (1899-1999): 39-58. Universidad de Sevilla, Sevilla.

BLANCO FREIJEIRO, A. y ROTHENBERG, B. (1981): Exploración Arqueometalúrgica de Huelva (E.A.H.). Labor-Río Tinto Minera, Barcelona.

BLÁNQUEZ, J. y PÉREZ RUIZ, Ma . (2004): “Apuntes y consideraciones para una biografía sobre Antonio García y Bellido", en J. Blánquez y Mª . Pérez Ruiz (eds.), Antonio García y Bellido y su legado a la Arqueología Española (1903-1972): 19-58. Serie Varia 5, Universidad Autónoma de Madrid. Madrid.

BOSCH GIMPERA, P. (1915): El problema de la cerámica ibérica. Memorias de la Comisión de Investigaciones Paleontológicas y Prehistóricas. Madrid.

- (1928): "Relaciones entre el arte ibérico y el griego", Archivo de Prehistoria Levantina 1: 163-176.

- (1980): Memòries. Biografies i Memòries, 5. Edicions 62. Barcelona.

CARRIAZO y ARROQUIA, J. de M. (1923): Las ideas sociales en Juan Luis Vives. Tesis Doctoral inédita. Universidad Central de Madrid, Madrid.

- (1924): "Licurgo en España. Notas a Salomón Reinach", Actas y Memorias de la Sociedad Española de Antropología, Etnografía y Prehistoria 3: 161-173.

- (1925a): "La cultura de El Argar en el Alto Guadalquivir. Estación de Quesada", Actas y Memorias de la Sociedad Española de Antropología, Etnografía y Prehistoria 4: 173-191.

- (1925b): "La tabla de Tíscar", Don Lope de Sosa 13 (148): 110-114.

- (1925c): “Cerámica romana: nueva estampilla de alfarero en un plato de Quesada", Don Lope de Sosa 13 (153): 269-270.

- (1925d): "El sarcófago cristiano de Berja", Archivo Español de Arte y Arqueología 1 (2): 197-218. 
- (1925e): "Precursores españoles de la Reforma: los herejes de Durango", Actas y Memorias de la Sociedad Española de Antropología, Etnografía y Prehistoria 4 (1): 35-69.

- (1926a): "Para el sarcófago cristiano de Berja", Archivo Español de Arte y Arqueología 2 (4-5): 161-162.

- (1926b): "Salvador Páramo y López, imaginero madrileño", Arte Español 1926 (2).

- (1926c): "La atalaya de Tíscar y el infante don Enrique", Boletín de la Sociedad Española de Excursiones 34: 116-143.

- (1927a): "Las ideas sociales en Juan Luis Vives", Actas y Memorias de la Sociedad Española de Antropología, Etnografia y Prehistoria 6 (1-2): 49-134.

- (1927b): "Los relieves de la guerra de Granada en el coro de Toledo", Archivo Español de Arte y Arqueología 3 (7): 19-70.

- (ed.) (1927c): Mosén Diego de Valera: Crónica de los Reyes Católicos. Anejo de la Revista de Filología Española 8. Centro de Estudios Históricos. Madrid.

- (1929a): Arquitectura prehistórica. Cartillas de Arquitectura Española 1. Madrid.

- (1929b): "Correspondencia de don Antonio Ponz con el conde del Águila", Archivo Español de Arte y Arqueología 5 (14): 157-184.

- (1929c): "Retrato y elogio de Baltasar de Alcázar por Francisco Pacheco", Don Lope de Sosa 17: 99-104.

- (1930): Alcázar de Sevilla. El Arte en España 29. Barcelona.

- (1931a): "La escultura tartesia. Nuevos cilindros grabados con estilizaciones humanas del Eneolítico andaluz", Archivo Español de Arte y Arqueología 7 (20): 97-111.

- (1931b): "Un sarcófago protocristiano en el Prado de Sevilla", Archivo Español de Arte y Arqueología 7 (20): 113-118.

- (1931c): "Esculturas hispánicas del Cortijo del Álamo", Archivo Español de Arte y Arqueología 7 (20): 163-166.

- (1931d): "Nuevos fragmentos inéditos de la 'Lex Coloniae Genetivae Juliae", Investigación y Progreso 5: 1920.

- (1932): "Estela discoidea de Quesada", Archivo Español de Arte y Arqueología 8 (24): 213-218.

- (1935a): "Les fouilles d'Itálica", Bulletin de l'Office International des Instituts d'Archéologie et d'Histoire de l'Art 1 (3): 25-33.

- (1935b): "Estado actual de las excavaciones de Itálica: La manzana del Gimnasio". Anuario del Cuerpo Facultativo de Archiveros, Bibliotecarios y Arqueólogos. Homenaje a Mélida. III: 305-319. Madrid.
- (1940a): El Victorial: Crónica de don Pero Niño, conde de Buelma, por su alférez Gutierre Díez de Games. Colección de Crónicas Españolas 1. Espasa-Calpe. Madrid.

- (1940b): Crónica de don Álvaro de Luna, condestable de Castilla, maestre de Santiago. Colección de Crónicas Españolas 2. Espasa-Calpe. Madrid.

- (1940c): Hechos del condestable Miguel Lucas de Iranzo. Colección de Crónicas Españolas 3. EspasaCalpe. Madrid.

- (1941): Memorial de diversas hazañas. Colección de Enrique IV, ordenada por Mosén Diego de Varela. Colección de Crónicas Españolas 4. EspasaCalpe. Madrid.

- (1943a): Crónica de los Reyes Católicos, por su secretario Fernando del Pulgar. Colección de Crónicas Españolas 5. Espasa-Calpe. Madrid.

- (1943b): Crónica de los Reyes Católicos, por su secretario Fernando del Pulgar. II Colección de Crónicas Españolas 6. Espasa-Calpe. Madrid.

- (1945): Historia del Emperador Carlos V, escrita por su cronista el magnifico caballero Pedro Mexía, veinticuatro de Sevilla. Colección de Crónicas Españolas 7. Espasa-Calpe. Madrid.

- (1946a): Crónica del Halconero de Juan II, Pedro Carrillo de Huete. Colección de Crónicas Españolas 8. Espasa-Calpe. Madrid.

- (1946b): Refundición de la Crónica del Halconero de Juan II, por el obispo don Lope Barrientos. Colección de Crónicas Españolas 9. Espasa-Calpe. Madrid.

- (1946c): "El capítulo de Canarias en la 'Crónica de Juan II'. (Versión original, inédita, de Álvar García de Santa María", Revista de Historia Canaria XII (73): 1-9.

— (1946d): "Cartas de la frontera de Granada", Al-Andalus 11 (1): 69-130.

- (1947a): "La Edad del Bronce”, en R. Menéndez Pidal (coord.), Historia de España. Tomo I. España Primitiva: 755-852. Volumen I. Espasa Calpe, Madrid.

- (1947b): "La guerra de los moriscos vista desde una plaza fronteriza. (Extractos de las actas capitulares de Quesada)", Revista de Estudios de la Vida Local 6 (33): 325-342, 6 (34): 528-545 y 6 (35): 713-730.

- (1948): "Un alcalde entre los cristianos y los moros, en la frontera de Granada", Al-Andalus 13 (1): 35-96.

- (1951): Crónica de los Reyes Católicos, por Alonso de Santa Cruz. Escuela de Estudios Hispano-Americanos I-II. Madrid-Sevilla.

- (1952): "Notas para una edición de la Crónica de Álvar García". Estudios dedicados a Menéndez 
Pidal III: 489-505. Consejo Superior de Investigaciones Científicas, Madrid.

- (1958): "Un tesoro digno de Argantonio: Joyas de oro prehistóricas del cerro de El Carambolo", $A B C$, Sevilla, 16 de Noviembre de 1958: 37-41.

- (1959): "Las joyas y excavaciones de El Carambolo", Archivo Hispalense 30 (93-94): 153-162.

- (1960): "El mensaje de Tartessos", Anales de la Universidad Hispalense 20: 21-55.

- (1961-62): "El dolmen de Ontiveros (Valencina de la Concepción, Sevilla)", Homenaje al profesor Cayetano de Mergelina: 209-229. Universidad de Murcia, Murcia.

- (1964): "Panorama general de las novedades arqueológicas en la Baja Andalucía, principalmente protohistóricas”, en A. Beltrán (ed.), VIII Congreso Nacional de Arqueología (Sevilla, 1963): 18-31. Secretaría General de los Congresos Arqueológicos Nacionales, Zaragoza.

- (1966a): "Memoria de los trabajos de excavación y hallazgos arqueológicos realizados en la zona de Sevilla durante el año 1965", Noticiario Arqueológico Hispánico 8-9 1965: 301-312.

- (1966b): “Alfredo Cazabán y la defensa del tesoro artístico y arqueológico", Boletín del Instituto de Estudios Giennenses 13 (51): 31-36.

- (1969a): "El cerro del Carambolo". Tartessos y sus problemas. V Symposium Internacional de Prehistoria Peninsular (Jerez, 1968): 311-340. Publicaciones Eventuales 13. Instituto de Arqueología y Prehistoria. Universidad de Barcelona, Barcelona.

- (1969b): "Historia de la guerra de Granada", en R. Menéndez Pidal (coord.), Historia de España XVII (1) : 385-914. Espasa-Calpe. Madrid.

- (1970a): El tesoro y las primeras excavaciones de El Carambolo (Camas, Sevilla). Excavaciones Arqueológicas en España 68. Ministerio de Educación y Ciencia, Madrid.

- (1970b): El tesoro y las primeras excavaciones de Ébora (Sanlúcar de Barrameda). Excavaciones Arqueológicas en España 69. Ministerio de Educación y Ciencia, Madrid.

- (1972): “Con Don Manuel Gómez-Moreno en el Centro de Estudios Históricos", Homenaje al Profesor Carriazo II: xli-lxi. Facultad de Filosofía y Letras, Universidad de Sevilla. Sevilla.

- (1973): Tartessos y El Carambolo. Investigaciones arqueológicas sobre la Protohistoria de la Baja Andalucía. Arte de España 4. Dirección General de Bellas Artes, Ministerio de Educación y Ciencia. Madrid.
- (1974/1980): Protohistoria de Sevilla. En el vértice de Tartesos. Ayuntamiento de Sevilla-Guadalquivir S.L. Ediciones. Barcelona-Sevilla.

- (1975a): "El dolmen de Hidalgo (junto a la desembocadura del Guadalquivir), y las contiguas sepulturas en fosa eneolíticas", en A. Beltrán (ed.), XIII Congreso Nacional de Arqueología (Huelva, 1973): 327-332. Secretaría General de los Congresos Arqueológicos Nacionales, Zaragoza.

- (1975b): Colección diplomática de Quesada. Instituto de Estudios Giennenses, Jaén.

- (1977): El maestro Gómez-Moreno contado por el mismo. Discurso leído el día 8 de Mayo de 1977, en su recepción pública, por el Excmo. Sr. D. Juan de Mata Carriazo y Arroquia y contestación del Excmo. Sr. D. Emilio García Gómez. Real Academia de la Historia, Sevilla.

- (1982a): Crónica de Juan II de Castilla, por Alvar García de Santa María. Real Academia de la Historia, Madrid.

- (1982b): "La puerta del Anfiteatro en el recinto de Itálica”. Homenaje al Prof. Dr. Hernández Díaz I: 35-49. Universidad de Sevilla, Sevilla.

CARRIAZO, J. de M. y RADDATZ, K. (1960): "Primicias de un corte estratigráfico en Carmona", Archivo Hispalense 33 (103-104): 333-369.

CARRIAZO RUBIO, J.L. (2001): “Bosquejo biográfico de Don Juan de Mata Carriazo y Arroquia”, en J.L. Carriazo Rubio (ed.), Juan de Mata Carriazo y Arroquia. Perfiles de un centenario (1899-1999): 13-37. Universidad de Sevilla, Sevilla.

CASADO RIGALT, D. (2006): José Ramón Mélida (1856-1933) y la arqueología española. Anticuaria Hispánica 13. Real Academia de la Historia, Madrid.

CASTAÑEDA y ALCOVER, V. (1934): "El Excmo. Sr. D. José Ramón Mélida”, Boletín de la Real Academia de la Historia 104 (1): 5-40.

COLLANTES DE TERÁN y DELORME, F. (1941): “Trabajos en Itálica”, Archivo Español de Arqueología 14 (40): 235-238.

- (1956): Sevilla en la Antigüedad y Edad Media, Estudio Topográfico y Arqueológico. Tesis Doctoral, Universidad de Sevilla. Sevilla.

- (1969): "El dolmen de Matarrubilla", Tartessos y sus problemas. V Symposium Internacional de Prehistoria Peninsular (Jerez, 1968): 47-61. Publicaciones Eventuales 13. Instituto de Arqueología y Prehistoria, Universidad de Barcelona. Barcelona.

- (1977): Contribución al estudio de la topografía de Sevilla en la Antigüedad y en la Edad Media, según 
los más recientes hallazgos. Academia de Bellas Artes de Santa Isabel de Hungría, Sevilla.

DÍAZ-ANDREU GARCÍA, M. (2003): “Arqueología y Dictaduras: Italia, Alemania y España”, en F. Wulff y M. Álvarez (eds.), Antigüedad y Franquismo (1936-1975): 33-74. Diputación Provincial de Málaga, Málaga.

- (2004): "Mélida: génesis, pensamiento y obra de un maestro", en J.R. Mélida y Alinari, Arqueología Española: ix-clxviii. Urgoiti Editores, Pamplona.

- (1996): “Arqueólogos españoles en Alemania en el primer tercio del siglo XX. Los becarios de la Junta de Ampliación de Estudios e Investigaciones Científicas", Madrider Mitteilungen 37: 205-224.

DOMÍNGUEZ ORTIZ, A. (1989): "In Memoriam: Excmo. Sr. D. Juan de Mata Carriazo y Arroquia", Revista del Centro de Estudios Históricos de Granada y su Reino 2a S. 3: 275-276.

- (1997): "Prólogo", en J. de M. Carriazo, La boda del Emperador: notas para una historia de amor en el Alcázar de Sevilla. Ayuntamiento de Sevilla-Patronato del Real Alcázar, Sevilla.

ESCACENA CARRASCO, J.L. (2004): "Tartessos (des)orientado", en B. Costa y J.H. Fernández Gómez (eds.), Colonialismo e interacción cultural. El impacto fenicio-púnico en las sociedades autóctonas de Occidente. XVIII Jornadas de Arqueología Fenicio-Púnica (Eivissa, 2003): 7-55. Treballs del Museu Arqueològic d'Eivissa i Formentera, Eivissa.

- (2010): "El Carambolo y la construcción de la arqueología tartésica", en $\mathrm{M}^{\mathrm{a}}$.L. de la Bandera y E. Ferrer (eds.), El Carambolo. 50 años de un tesoro (Sevilla, 2008): 99-148. Universidad de Sevilla. Sevilla.

FERNÁNDEZ GÓMEZ, F. (2001): "El tesoro de 'El Carambolo' en la prensa de la época", Revista de Arqueología 22 (237): 30-41.

GALLEGO ROCA, F.J. (ed.) (1995): Epistolario de Leopoldo Torres Balbás a Antonio Gallego Burín. Universidad de Granada-Diputación Provincial de Granada, Granada.

GARCÍA y BELLIDO, A. (1925): “Cerrajes artísticos de la Escuela de Madrid”, Arte Español 8 (6): 225-237.

- (1926): "En el Museo del Prado: Conferencias de arte cristiano: evangelio del centurión, la Santa Faz; San Sebastián", Boletín de la Sociedad Española de Excursionistas 34: 277-286.

- (1928): "Historia de la cerrajería artística madrileña", Boletín de la Sociedad Española de Excursionistas 36: 261-294.

- (1928): "Rutilio Gaci", Archivo Español de Arte y Arqueología 4 (12): 238-243.
- (1929): Estudios del Barroco español. Avance para una monografía de los Churrigueras. Tesis Doctoral inédita. Universidad de Madrid. Madrid.

- (1929): "Estudios del Barroco español. Avances para una monografía de los Churrigueras", Archivo Español de Arte y Arqueología 5 (13): 21-86.

- (1929): La arquitectura romana en España. Cartillas de Arquitectura Española 2. Madrid.

- (1930): "Estudios del Barroco español. Avances para una monografía de los Churrigueras. II", Archivo Español de Arte y Arqueología 6 (17): 135-187.

- (1931): "Las relaciones entre el arte etrusco y el ibero", Archivo Español de Arte y Arqueología 7 (20): 119-148.

- (1931): "Las relaciones entre el arte etrusco y el ibero", Investigación y Progreso 5 (9): 128-130.

- (1931): "La Bicha de Balazote", Archivo Español de Arte y Arqueología 7 (21): 249-270.

- (1936): Los hallazgos griegos en España. Centro de Estudios Históricos. Madrid.

- (1960): Colonia Aelia Augusta Italica. Consejo Superior de Investigaciones Científicas. Madrid.

- (1964): "Las casas de Itálica”, en A. Beltrán (ed.), VIII Congreso Nacional de Arqueología (Sevilla, 1963): 454-460. Secretaría General de los Congresos Arqueológicos Nacionales, Zaragoza.

GARCÍA DE SANTA MARÍA, Á. (1419/1946): “El capítulo de Canarias en la 'Crónica de Juan II'. (Versión original, inédita, de Álvar García de Santa María”, en J. de Mata Carriazo (ed.), Revista de Historia Canaria XII (73): 1-9.

GARCÍA SANTOS, J.C. (2003-2005): “Los programas y didáctica de la arqueología presentados en las oposiciones a cátedras de universidad (19001940)", Archaia 3-5: 272-282.

GÓMEZ-MORENO MARTÍNEZ, M. (1905): “Arquitectura tartesia: la necrópoli de Antequera”, Boletín de la Real Academia de Historia 47 (3): 81-132.

- (1922): "De epigrafía ibérica: el plomo de Alcoy", Revista de Filología Española 9: 341-366.

- (1928a): La novela de España. Imprenta de Antonio Marzo, Madrid.

- (1928a/1974): La novela de España. La Vela Latina 28. Ediciones Júcar, Madrid.

- (1933): "La cerámica primitiva ibérica", Homenagem a Martins Sarmiento: miscelánea de estudos em honra do investigador vimaranense no centenário do seu nascimento (1833-1933): 125-136. Sociedade Martins Sarmento, Guimarães.

- (1951-1958/1977): "Un currículum vitae, autógrafo, del maestro Gómez-Moreno", en J. de M. 
Carriazo, El maestro Gómez-Moreno contado por el mismo. Discurso leído el día 8 de Mayo de 1977, en su recepción pública, por el Excmo. Sr. D. Juan de Mata Carriazo y Arroquia y contestación del Excmo. Sr. D. Emilio García Gómez: 53-62. Real Academia de la Historia, Sevilla.

- (1958): Adam y la Prehistoria. Historia primitiva del hombre. Tecnos, Madrid.

GÓMEZ-MORENO MARTÍNEZ, M. y CARRIAZO y ARROQUIA, J. de M. (1962): Memorias del reinado de los Reyes Católicos, que escribía el bachiller Andrés Bernáldez. Real Academia de la Historia, Madrid.

GONZÁLEZ JIMÉNEZ, M. (2001): “Don Juan de Mata Carriazo, historiador de la frontera de Granada", en J.L. Carriazo Rubio (ed.), Juan de Mata Carriazo y Arroquia. Perfiles de un centenario (1899-1999): 111-127. Universidad de Sevilla, Sevilla.

GRACIA ALONSO, F. (2003): "Pere Bosch Gimpera y la formación de l'Escola de Barcelona (19151939)", en J. Barberà y J. García Roselló (eds.), L'Arqueologia a Catalunya durant la República i el Franquisme (1931-1975). Homenatge a Marià Ribas i Beltrán (1902-1996) en el centenari del seu naximent (Mataró, 2002): 31-91. Museu de Mataró, Mataró.

GRACIA ALONSO, F. (2009): La arqueología durante el primer franquismo (1939-1956). Bellaterra Arqueología, Barcelona.

GRACIA, F. y FULLOLA, J.Mª (2006): El sueño de una generación. El crucero universitario por el Mediterráneo de 1933. Universitat de Barcelona, Barcelona.

GRACIA, F.; FULLOLA, J.M ${ }^{\mathrm{a}}$ y VILANOVA, F. (2003): 58 anys $i 7$ dies. Correspondència de Pere Bosch Gimpera a Lluis Pericot (1919-1974). Universitat de Barcelona, Barcelona.

LADERO QUESADA, M.A. (2001): "Don Juan de Mata Carriazo, historiador de la guerra de Granada”, en J.L. Carriazo Rubio (ed.), Juan de Mata Carriazo y Arroquia. Perfiles de un centenario (1899-1999): 129-141. Universidad de Sevilla, Sevilla.

LUZÓN NOGUÉ, J.Ma. (1999): Sevilla la Vieja. Un paseo histórico por las ruinas de Itálica. Fundación Focus-Abengoa, Sevilla.

MALUQUER DE MOTES i NICOLAU, J. (1955): “El proceso histórico de las primitivas poblaciones peninsulares. I", Zephyrus 6: 145-169.

- (1957): "De metalurgia tartesia: el bronce Carriazo", Zephyrus 8 (1): 157-168.
- (1954-58): El yacimiento hallstáttico de Cortes de Navarra: Estudio crítico. I-II. Institución Príncipe de Viana, Pamplona.

- (1958a): Excavaciones arqueológicas en el Cerro del Berrueco (Salamanca). Acta Salmanticensia XIV. Universidad de Salamanca. Salamanca.

- (1958b): El castro de los Castillejos en Sanchorreja: estudio de las excavaciones realizadas por Juan Cabré, Joaquín $M^{a}$. de Navascués y Emilio Camps, de 1931 a 1935. Diputación Provincial de Ávila, Ávila.

- (1958c): "Nuevos hallazgos en el área tartésica", Zephyrus 9 (2): 201-219.

- (1958d/1994): Excavaciones de 'El Carambolo', Sevilla. Notas y experiencias personales. Caderno de Apontamentos de Octubre de 1958. Clásicos de Arqueología de Huelva 5. Diputación de Huelva, Huelva. - (1959): "El tesoro de "El Carambolo"”. En E. Kukahn y A. Blanco Freijeiro, El tesoro de 'El Carambolo’, Archivo Español de Arqueología 32 (99100): 48-49.

- (1960): "Nuevas orientaciones en el problema de Tartessos". I Symposium de Prehistoria de la Península Ibérica (Pamplona, 1959): 273-307. Institución Príncipe de Viana. Diputación Foral de Navarra. Pamplona.

— (1969b): “Tartessos y su 'Historia”". Tartessos y sus problemas. V Symposium Internacional de Prehistoria Peninsular (Jerez, 1968): 389-406. Publicaciones Eventuales, 13. Instituto de Arqueología y Prehistoria. Universidad de Barcelona. Barcelona.

- (1970): Tartessos. La ciudad sin historia. Ediciones Destino. Barcelona.

MANCEBO ALONSO, Ma.F. (1988): La Universidad de Valencia en Guerra. La F.U.E. (1936-39). Ajuntament de València-Universitat de València, Valencia.

MEDEROS MARTÍN, A. (1999): "El joven Bosch Gimpera y la primera estructuración de la Prehistoria en España", Boletín del Seminario de Estudios de Arte y Arqueología 65: 9-28.

MÉLIDA y ALINARI, J.R. (1896): "La Bicha de Balazote", Revista de Archivos, Bibliotecas y Museos 8: 140-142.

MERGELINA y LUNA, C. de (1920): Arquitectura megalitica en la Península Ibérica. Tesis Doctoral inédita, Universidad Central de Madrid. Madrid.

- (1922): "La necrópoli tartesia de Antequera", Actas y Memorias de la Sociedad Española de Antropología, Etnografía y Prehistoria 1: 37-90.

NIETO GALLO, G. (1964): "Discurso de clausura", en A. Beltrán (ed.), VIII Congreso Nacional de 
Arqueología (Sevilla, 1963): 53-79. Secretaría General de los Congresos Arqueológicos Nacionales. Zaragoza.

PASAMAR, G. y PEIRÓ, I. (2002): Diccionario Akal de Historiadores españoles contemporáneos (18401980). Akal, Madrid.

PÉREZ RUIZ, Ma (2008): "La formación científica de Antonio García y Bellido y la escuela arqueológica alemana. 1930-1935”, en S. González Reyero, M. Pérez Ruiz y C.I. Bango (eds.), Una mirada sobre el patrimonio histórico. Líneas de investigación arqueológica en la Universidad Autónoma de Madrid. II Jornadas de Investigación del Departamento de Prehistoria y Arqueología de Jóvenes investigadores de la Comunidad de Madrid (Madrid, 2005): 63-78. Universidad Autónoma de Madrid, Madrid.

PERICOT GARCÍA, L. (1972): Reflexiones sobre la Prehistoria hispánica. Discurso leído el día 10 de diciembre de 1972 en el acto de su recepción pública. Real Academia de la Historia, Madrid.

POLAINO ORTEGA, L. (1972): “Apuntes bio-bibliográficos”. Homenaje al Profesor Carriazo. II: xiiixl. Facultad de Filosofía y Letras. Universidad de Sevilla. Sevilla.

QUERO CASTRO, S. (2002): "La investigación del Paleolítico en Madrid durante el franquismo
(1936-1971)", Bifaces y elefantes. La investigación del Paleolítico Inferior en Madrid. Zona Arqueológica 1: 168-193.

SCHULTEN, A. (1922a): Tartessos; ein beitrag zur ältesten geschichte des Westens. Abhandlungen aus dem Gebiet der Auslandskunde. L. Friederichsen. Hamburg.

- (1922b/2006): Tartessos. Contribución a la historia más antigua de Occidente. Almuzara, Córdoba.

- (1930): "Die Etrusker in Spanien", Klio 23: 365432.

- (1945): Tartessos. Colección Austral, 1471. Espasa Calpe, Madrid.

SOBREQUÉS i CALLICÓ, J. (ed.) (1991): Epistolari de Francesc Martorell $i$ Trabal $i$ de Pere Bosch $i$ Gimpera amb Ramón d'Abadal i de Vinyals $i$ amb Ferran Valls i Taberner: 1908-1931. Colecció d'Epistolaris Catalans del segle XX, 2. PPU, Barcelona.

TARRADELL MATEU, M. (1969): “El problema de Tartessos visto desde el lado meridional del Estrecho de Gibraltar", Tartessos y sus problemas. V Symposium Internacional de Prehistoria Peninsular (Jerez de la Frontera, 1968): 221-232. Publicaciones Eventuales 13. Universidad de Barcelona, Barcelona. 